\title{
Measuring and Interpreting Nuclear Transport in Neurodegenerative Disease-The Example of C9orf72 ALS
}

\author{
Marije F. W. Semmelink, Anton Steen and Liesbeth M. Veenhoff *(D) \\ European Research Institute for the Biology of Ageing, University of Groningen, \\ University Medical Center Groningen, 9713 AV Groningen, The Netherlands; m.f.w.semmelink@rug.nl (M.F.W.S.); \\ a.steen@umcg.nl (A.S.) \\ * Correspondence: 1.m.veenhoff@rug.nl
}

check for updates

Citation: Semmelink, M.F.W.; Steen, A.; Veenhoff, L.M. Measuring and Interpreting Nuclear Transport in Neurodegenerative Disease-The Example of C9orf72 ALS. Int. J. Mol. Sci. 2021, 22, 9217. https://doi.org/ $10.3390 /$ ijms 22179217

Academic Editor: Patrizia Lavia

Received: 16 July 2021

Accepted: 18 August 2021

Published: 26 August 2021

Publisher's Note: MDPI stays neutral with regard to jurisdictional claims in published maps and institutional affiliations.

Copyright: (c) 2021 by the authors. Licensee MDPI, Basel, Switzerland. This article is an open access article distributed under the terms and conditions of the Creative Commons Attribution (CC BY) license (https:// creativecommons.org/licenses/by/ $4.0 /)$.

\begin{abstract}
Transport from and into the nucleus is essential to all eukaryotic life and occurs through the nuclear pore complex (NPC). There are a multitude of data supporting a role for nuclear transport in neurodegenerative diseases, but actual transport assays in disease models have provided diverse outcomes. In this review, we summarize how nuclear transport works, which transport assays are available, and what matters complicate the interpretation of their results. Taking a specific type of ALS caused by mutations in C9orf72 as an example, we illustrate these complications, and discuss how the current data do not firmly answer whether the kinetics of nucleocytoplasmic transport are altered. Answering this open question has far-reaching implications, because a positive answer would imply that widespread mislocalization of proteins occurs, far beyond the reported mislocalization of transport reporters, and specific proteins such as FUS, or TDP43, and thus presents a challenge for future research.
\end{abstract}

Keywords: nuclear transport; nuclear pore complex; nuclear transport receptor; C9orf72; amyotrophic lateral sclerosis (ALS)

\section{Introduction \\ 1.1. Nucleocytoplasmic Transport}

Nucleocytoplasmic transport (NCT) occurs through nuclear pore complexes (NPCs), large protein complexes embedded in the nuclear membrane. NPCs facilitate and regulate the import and export of proteins and RNA between the nucleus and cytoplasm. Small proteins will rapidly diffuse through the NPC, but the passage of larger molecules is hindered by the NPC's permeability barrier [1,2]. The association of proteins or RNAs with specific importins, exportins, and transportins, grouped together as nuclear transport receptors (NTRs), facilitates the passage of macromolecules, large and small, across the barrier (Figure 1).

The NPC is made up of proteins called nucleoporins (Nups) that build the cylindrical structure embedded in the nuclear membrane. FG-Nups containing phenylalanine-glycine (FG) repeats constitute roughly half of the mass of the NPCs [3] with about 200 copies of FG-Nups found in each pore [3,4]. The precise nature of the permeability barrier formed by the FG-Nups is still under debate, but what is clear is that the NTRs associate directly with the FG-Nups, even with specificity to certain Nups over others [5-10], to facilitate the passage of NTR-cargo complexes. Additionally, a pool of importin- $\beta$ functions as a stable component of the NPC's permeability barrier [11]. The differential localization of NPC-associated proteins in a single yeast nucleus suggests that NPCs may even have specialized transport functions [12].

In baker's yeast, there are 19 known NTR [13-16], whereas in human cells, 30 NTRs [17] are identified. The substrate specificity of some, but not all NTRs has been mapped, and jointly they bind a large and diverse group of cargoes, while some redundancies exist [18]. The importin- $\beta$ superfamily is the largest class of NTRs; they can either directly bind to 
their cargo, or via an adaptor protein, an importin- $\alpha$ isoform [19]. Exportins include CRM1, LOS1, and the MEX67-MTR2 (or human TAP/p15) complex for mRNAs and tRNAs [20], MSN5 for tRNAs, and CAS/CSE1 specifically exports Imp $\alpha /$ Kap60 [21]. Of note, while general protein export is mediated only by the major exportin CRM1, many importins cooperate for general protein import. NTRs bind their cargoes through a nuclear localization signal (NLS) or a nuclear export signal (NES) encoded on a cargo molecule.
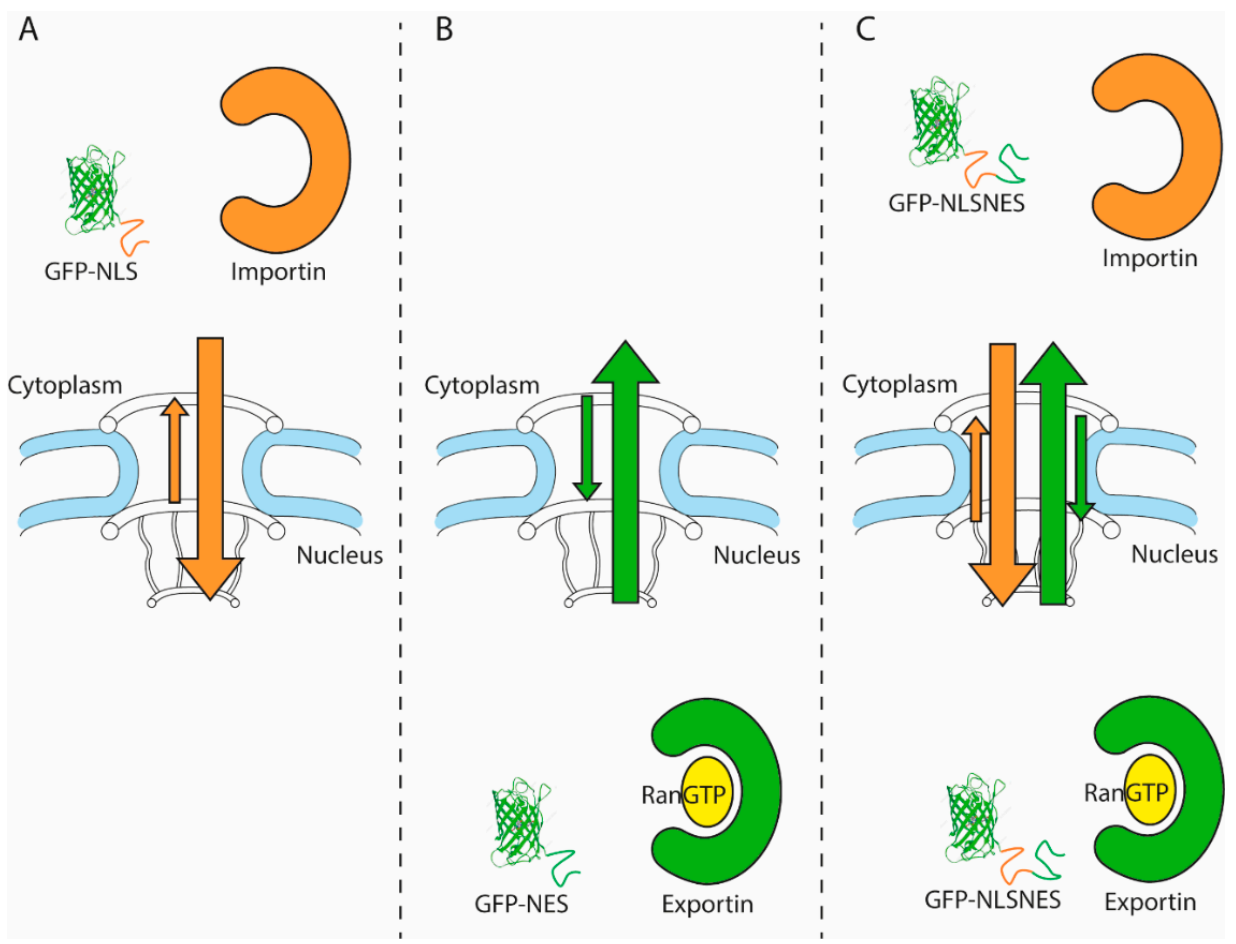

Figure 1. Nucleocytoplasmic transport can be measured with fluorophore-tagged transport reporters. (A) GFP tagged with an NLS accumulates in the nucleus owing to constant active import, which is faster than the passive leak in the opposite direction. (B) GFP tagged with an NES accumulates in the cytosol owing to constant active export, which overpowers passive influx. (C) GFP tagged with both an NLS and NES sequence accumulates depending on the strongest signal, as it is both actively imported and exported and passively diffuses across the nuclear pore. Passive diffusion (=influx and efflux) is dependent on the concentration gradient of the reporter, the number of NPCs, and their permeability.

Ran, a member of the Ras family of small GTPases, is in its GTP bound state in the nucleus and its GDP bound state in the cytosol. This gradient functions to ensure that the cargoes are accumulated in the nucleus or cytosol by promoting the removal of cargo from importins and the loading of cargo to exportins [22-24]. Whereas importins bind to either the NLS of their cargo or to the RanGTP, exportins bind to both the NES of their cargo and the RanGTP cooperatively. Therefore, cargo release from importins depends on RanGTP binding, while cargo release from exportins needs RanGTP hydrolysis. RanGTP levels in the nucleus are maintained by the guanine nucleotide exchange factor RCC1 or RanGEF. RanGTP is converted to RanGDP in the cytoplasm by the GTPase-activating protein RanGAP. NCT is thus an interplay between the NPCs, with a number of different NTRs recognizing cargo through sorting signals and a gradient of Ran in its GTP or GDP bound state.

\subsection{Amyotrophic Lateral Sclerosis (ALS)}

ALS is a neurodegenerative disease that affects neurons in the brain and spinal cord. Amyotrophy is the degeneration of spinal motor neurons, which leads to denervation and muscle wasting. Lateral sclerosis refers to the scarring (sclerosis) of the lateral axons, which control voluntary movement [25]. In most cases, the cause for ALS remains unknown, but 
5-10\% of ALS cases are caused by autosomal dominantly inherited mutations [26], of which almost $40 \%$ in Caucasians are in C9orf72 [27]. Specifically, a $\mathrm{G}_{4} \mathrm{C}_{2}$ hexanucleotide is repeated up to thousands of times in C9-ALS patients [28,29], and translated via repeat-associated non-AUG (RAN) translation. This non-canonical initiation of translation allows elongation of a repeat sequence in the absence of an AUG starting codon, in multiple reading frames, thus leading to multiple dipeptide repeat proteins (DPRs) [30]. For C9orf72, the sense RNA encodes glycine-alanine (GA), glycine-proline (GP), and glycine-arginine (GR) repeat proteins. The antisense transcript produces proline-arginine (PR), glycine-proline (GP), and proline-alanine (PA) repeat proteins [31,32]. On a molecular level, C9-ALS disease is thus associated with multiple disease-related biomolecules, DNA, RNA, and DPRs. Hence, C9-ALS models introduce the $\mathrm{G}_{4} \mathrm{C}_{2}$ repeat DNA, or express or inject a single DPR of a certain length.

\subsection{Nucleocytoplasmic Transport and C9orf72 ALS}

A growing body of work suggests that changes in components of the nucleocytoplasmic transport machinery are related to neurodegenerative diseases (reviewed in [33-43]), but also specifically ALS. Firstly, the C9orf72 protein was found to interact with both importin- $\beta 1$ and Ran-GTPase [44]. Moreover, effects on toxicity were reported; it was found that overexpression of RanGAP reduces toxicity of $\mathrm{G}_{4} \mathrm{C}_{2}$ repeats [45], downregulation of NTRs enhances $\mathrm{G}_{4} \mathrm{C}_{2}$ toxicity [46], and toxicity caused specifically by $\mathrm{PR}_{50}-50$ repeats of PR-is reduced by NTR overexpression [47]. An overview of NCT related genes that modify toxicity can be found in the accompanying review by Vanneste et al [48]. Furthermore, $\mathrm{GA}_{50}$ was reported to bind RanGAP1 in cytoplasmic inclusions [49], and poly-PR and -GR can directly bind to importin- $\beta$ [50]. Moreover, the nuclear and cytoplasmic distributions of major protein components of NPCs were found to be altered in ALS [51]. Mislocalization or aggregation of NTRs has also been linked to C9-ALS (reviewed by Hutten and Dormann [39]) and mislocalization of NTRs and Nups has been shown in ALS post-mortem tissue and ALS models (reviewed in the accompanying review [48]. PR repeats are reported to directly bind to nuclear pores [52]. Further data linking altered NCT to C9-ALS include the following: nuclear RNA retention [46,52], mislocalization of Pom121 by poly-GA [49], reduced nuclear RCC1 (RanGEF) in C9orf72-carrier induced neurons [47], and increased cytoplasmic localization of neuronal RNA-binding protein Elav [53]. RanGAP was also found to be mislocalized in C9orf72-carrier induced neurons [47], but not in other models of C9orf72-associated neurodegeneration [47,54-56]. Thus, there is evidence from different model systems and experimental methods that nucleocytoplasmic transport components-NTRs, RanGAP, RanGEF, and Nups-are impacted in C9-ALS.

From the plethora of effects on NCT components, one would expect that the kinetics of NCT is impacted in C9-ALS. Establishing if the transport kinetics of NPCs in C9-ALS is altered is important, as a positive answer would suggest a common cause in ALS, i.e., mislocalization of many proteins, including ALS-related FUS and TDP43. A negative answer would suggest the NCT machinery is a robust system, and not causal to the phenotype of C9-ALS. This question has indeed been addressed in seven studies [45,50,52,55,57-59], which are summarized in Table 1; we included only those studies that make use of C9ALS models and mobile reporters. We did not include papers with full length proteins, as their localization may be impacted by other processes, such as retention. Table 1 shows the used reporters (i.e., usually a fluorescent protein with a specific NLS and/or NES sequence), the NTRs associated with the used NLS/NESs (importin- $\alpha / \beta$ complex, TNPO1 (Kap $\beta 2)$, and CRM1), the C9-ALS model (i.e., introduction of repeat DNA, or expression or injection of a specific DPR), and the cell model. From a brief look at the joint data, it is not obvious if transport kinetics are altered in C9-ALS, as some experiments report changes, while others do not. To understand what one may conclude from the results from these diverse experimental setups and why there are seemingly inconsistent outcomes, we next discuss commonly used transport assays to then come back to the nuclear transport process in more detail to illustrate the complications in interpreting their outcomes. 
Table 1. Transport studies of C9-ALS.

\begin{tabular}{|c|c|c|c|c|c|}
\hline \multicolumn{6}{|c|}{ Summary of Experimental Setup and Results of Nuclear Transport Studies in C9-ALS Models } \\
\hline \multirow{2}{*}{$\begin{array}{c}\text { Reporter } \\
\text { (Localization in Wildtype) }\end{array}$} & \multirow{2}{*}{ NTR } & \multirow{2}{*}{ Model } & \multicolumn{2}{|c|}{ Effect of Indicated C9-ALS DNA Repeats or DPRs on Transport Reporter } & \multirow{2}{*}{ Reference } \\
\hline & & & Changed & Unchanged & \\
\hline $\begin{array}{l}\text { (A) } \mathrm{NLS}_{\mathrm{Sv} 40^{-}} \text {-tdTomato-NES } \\
\text { (nuclear) }\end{array}$ & \multirow{5}{*}{$\operatorname{Imp} \alpha / \beta$ complex CRM1 } & $\left(\mathrm{G}_{4} \mathrm{C}_{2}\right)_{\mathrm{n}}$ expression in C9-ALS iPSNs & Recovery of nuclear fluorescence after FRAP is decreased & & \multirow{5}{*}{ Zhang $2015[45]$} \\
\hline $\begin{array}{c}\text { (B) } \mathrm{NLS}_{\mathrm{S} Y 40^{-}} \text {-NES }_{\text {(nuclear) }} \text { PKI } \\
\end{array}$ & & $\frac{\left(\mathrm{G}_{4} \mathrm{C}_{2}\right)_{30}}{20}$ & \multirow{2}{*}{ Nuclear intensity is decreased } & & \\
\hline 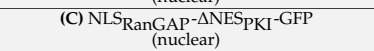 & & $\begin{array}{l}\text { expression in Drosophila } \\
\text { salivary gland cells }\end{array}$ & & & \\
\hline $\begin{array}{l}\text { (D) } \mathrm{NLS}_{\mathrm{S} 4040} \text {-NES SKI-GFP } \\
\text { (nuclear excluded) }\end{array}$ & & $\left(\mathrm{G}_{1} \mathrm{C}_{2}\right)_{20}$ & & & \\
\hline 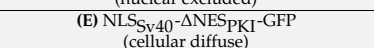 & & expression in motor neurons & Nuclear exclusion is increased & & \\
\hline $\begin{array}{l}\text { (F) GFP-NLS SV40-NESPKI } \\
\text { (nuclear excluded) }\end{array}$ & Imp $\alpha / \beta$ complex CRM1 & $\mathrm{PR}_{20}$ peptide injection in U2OS cells & $\begin{array}{l}\text { Nuclear intensity after export inhibition by Leptomycin } B \text { is decreased }\left(\mathrm{PR}_{20}\right. \\
\text { dose-dependent })\end{array}$ & & Shi 2017 [52] \\
\hline $\begin{array}{l}\text { (H) RFP-NLLSTDP } \\
\text { (nuclear) }\end{array}$ & $\operatorname{Imp} \alpha / \beta$ complex & \multirow[t]{2}{*}{ DPR expression in HeLa cells } & $\begin{array}{l}\text { Cytoplasmic intensity (C/T) is increased (more so with } \mathrm{GA}_{149} 9^{-\mathrm{GFP}} \text {, than with } \\
\mathrm{GA} 149-\mathrm{GFP}-\mathrm{NLS} \text { ) }\end{array}$ & Cytoplasmic intensity (C/T) is unchanged (GFP-GR $149 / \mathrm{PR}_{175}$-GFP) $\dagger$ & \multirow{2}{*}{ Khosravi 2017 [57] } \\
\hline $\begin{array}{l}\text { (I) RFP-NLSPY(hnRNPA1) } \\
\text { (nuclear) }\end{array}$ & TNPO1 & & & Cytoplasmic intensity (C/T) is unchanged $\left(\mathrm{GA}_{149} / \mathrm{GR}_{149} / \mathrm{PR}_{175}\right)$ & \\
\hline $\mathrm{NES}_{\mathrm{Rev}}$-tdTomatero-NLS $\mathrm{S}_{\mathrm{S} 40}$ & Imp $\alpha / \beta$ complex CRM1 & C9-ALS fibroblasts & Nuclear accumulation $(\mathrm{N} / \mathrm{C})$ is decreased & & Chou 2018 [55] \\
\hline $\begin{array}{l}\text { () } \mathrm{NLS}_{\mathrm{Sv} 40}-\mathrm{mNeon} \text { Green } \\
\text { (cytoplasmic } \\
\mathrm{x}^{-\mathrm{NES}}\end{array}$ & Imp $\alpha / \beta$ complex CRM1 & \multirow{2}{*}{ DPR peptide injection in HeLa Kyoto cells } & & $\begin{array}{l}\begin{array}{l}\text { Nuclear accumulation ( }(\mathrm{N} / \text { total) after export inhibition by Leptomycin B } \\
\text { is unchanged }\left(\mathrm{PR}_{20} / \mathrm{GR}_{20}\right)\end{array}\end{array}$ & \multirow{4}{*}{ Vanneste 2019 [58] } \\
\hline $\begin{array}{c}\text { (K) } \mathrm{NLS}_{\mathrm{PY}}(\mathrm{FUS})^{- \text {mNNeon Green }} 2 \mathrm{x}^{-\mathrm{NES}} \\
\text { (nuclear) }\end{array}$ & $\begin{array}{l}\text { TNPO1 } \\
\text { CRM1 }\end{array}$ & & & $\begin{array}{l}\text { Nuclear accumulation (N/total) after import inhibition by MGM9 is } \\
\text { unchanged }\left(\mathrm{PR}_{20} / \mathrm{GR}_{20}\right)\end{array}$ & \\
\hline 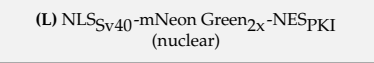 & \multirow[b]{2}{*}{$\operatorname{Imp} \alpha / \beta$ complex CRM1 } & \multirow{2}{*}{$\begin{array}{l}\text { mCherry-DPR lentiviral expression in Hela } \\
\text { Kyoto cells }\end{array}$} & \multirow[t]{2}{*}{ Nuclear accumulation $\begin{array}{c}\mathrm{N} / \mathrm{N} / \mathrm{total}) \text { ) ffter export inhibition by Leptomycin } \mathrm{B} \text { is } \\
\text { increased }(\mathrm{PR} 100)\end{array}$} & $\begin{array}{l}\text { Nuclear accumulation (N/total) after export inhibition by Leptomycin B } \\
\text { is unchanged }\left(\mathrm{PA}_{100} / \mathrm{GR}_{100} / \mathrm{GA}_{100}\right)\end{array}$ & \\
\hline (M) $\mathrm{NLS}_{\mathrm{c}-\mathrm{myc}-\mathrm{GFP}} 2 \mathrm{x}^{-\mathrm{NES}_{\mathrm{ik}} \beta 2}$ & & & & $\mathrm{~N} /$ total unchanged $\left(\mathrm{PA}_{100} / \mathrm{GA}_{100} / \mathrm{GR}_{100} /\right.$ & \\
\hline (O) IBB-domain ${ }_{\mathrm{KPNA2} 2}$-FRET sensor (nuclear) & $\operatorname{Imp} \beta$ & $\begin{array}{c}\text { DPR } \\
\text { Peptide injection in permeabilized primary } \\
\text { mouse cortical neurons }\end{array}$ & $\begin{array}{l}\text { Nuclear accumulation }(\mathrm{N} / \mathrm{C}) \text { is decreased (dose-dependent and more so with } \\
\left.\mathrm{PR}_{20} / \mathrm{GR}_{20} \text { than with } \mathrm{PR}_{10} / \mathrm{GR}_{10}\right) \text {, and minimal decrease with } \mathrm{G}_{10} / \mathrm{PA}_{10}\end{array}$ & Nuclear accumulation $(\mathrm{N} / \mathrm{C})$ is unchanged $\left(\mathrm{GP}_{10}\right)$ & \multirow{4}{*}{ Hayes 2020 [50] } \\
\hline 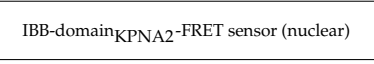 & $\operatorname{Imp} \beta$ & \multirow{3}{*}{$\begin{array}{l}\text { DPR } \\
\text { Peptide injection in permeabilized HeLa cells }\end{array}$} & $\begin{array}{l}\text { Nuclear accumulation }(\mathrm{N} / \mathrm{C}) \text { is decreased (more so with } \mathrm{PR}_{20} / \mathrm{GR}_{20} \text { than } \\
\left.\text { with } \mathrm{PR}_{10} / \mathrm{GR}_{10}\right)+++\end{array}$ & Nuclear accumulation $(\mathrm{N} / \mathrm{C})$ is unchanged $\left(\mathrm{PA}_{10} / \mathrm{GA}_{10} / \mathrm{GP}_{10}\right)$ & \\
\hline GST-GFP-NLS $S_{\mathrm{S} 40}$ (nuclear) & $\operatorname{Imp} \alpha / \beta$ complex & & $\begin{array}{l}\text { Nuclear accumulation }(\mathrm{N} / \mathrm{C}) \text { is decreased (more so with } \mathrm{PR}_{20} / \mathrm{GR}_{20} \text { than } \\
\left.\text { with } \mathrm{PR}_{10} / \mathrm{GR}_{10}\right)\end{array}$ & Nuclear accumulation $(\mathrm{N} / \mathrm{C})$ is unchanged $\left(\mathrm{PA}_{10} / \mathrm{GA}_{10} / \mathrm{GP}_{10}\right)$ & \\
\hline $\begin{array}{c}\text { (P) YFP-M9 } \text { hnRNPA1 }_{\text {-CFP }} \\
\text { (nuclear) }\end{array}$ & TNPO1 & & $\begin{array}{l}\text { Nuclear accumulation }(\mathrm{N} / \mathrm{C}) \text { is decreased (more so with } \mathrm{PR}_{20} / \mathrm{GR}_{20} \text { than } \\
\text { with } \mathrm{PR}_{10} / \mathrm{GR}_{10} \text { ) }\end{array}$ & Nuclear accumulation $(\mathrm{N} / \mathrm{C})$ is unchanged $\left(\mathrm{PA}_{10} / \mathrm{GA}_{10} / \mathrm{GP}_{10}\right)$ & \\
\hline 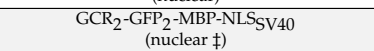 & \multirow{2}{*}{$\operatorname{Imp} \alpha / \beta$ complex } & \multirow{2}{*}{ DPR peptide addition to medium HeLa cells } & Nuclear accumulation $(\mathrm{N} / \mathrm{C})$ is decreased $\left(\mathrm{GR}_{25}\right)$ & & \multirow{2}{*}{ Hutten 2020 [59] } \\
\hline $\begin{array}{l}\mathrm{GCR}_{2}-\mathrm{GFP}^{2}-\mathrm{NLS}_{\mathrm{SV}} \\
\text { (nuclear } \mathrm{SV}_{40}\end{array}$ & & & Nuclear accumulation $(\mathrm{N} / \mathrm{C})$ is decreased $\left(\mathrm{GR}_{25}\right)$ 㧊 & & \\
\hline
\end{tabular}

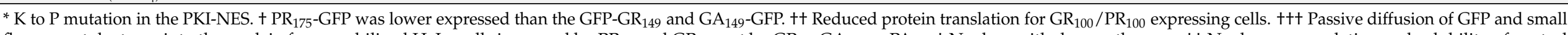

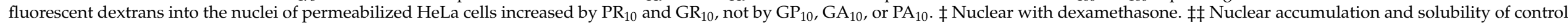
$\mathrm{GCR}_{2}-\mathrm{GFP}_{2}$ reporter (lacking NLS) not altered. 


\subsection{Commonly Used Nuclear Transport Assays}

The assays monitoring the kinetics of nuclear import and/or export generally use small inert reporters, such as GFP with a sorting signal, to control and limit reporter retention [60]. A GFP-NES or GFP-NLS reporter will passively pass the NPC down the concentration gradient owing to its small size, but additionally be actively transported owing to the NES/NLS [60]. Thus, its localization at steady state is the result of continuous nuclear import and efflux in the case of GFP-NLS, and export and influx in the case of GFP-NES (see Figure 1). The ratio between the fluorescence levels in the nucleus and cytosol provides the most common transport readout (the N/C ratio). The steady state localization of reporters encoding both an NLS and NES report on the ratio between import and export [61]. Provided that proper controls for the functionality of the NLS and NES are performed, this strategy has the advantage that, with a single cell line/model, one can monitor both import and export.

To measure actual rates of transport and influx/efflux, there are several strategies. Influx rates can be measured by monitoring the passive nuclear entry of larger cargoes, e.g., multimers of GFP, of proteinA, and of maltose-binding protein moieties [1,2]. The passive diffusion through the pores is affected by the overall size and shape of the protein, and its surface properties [62]. For example, surface histidines, cysteines, and arginines will facilitate the movement through the FG-Nup meshwork, and higher surface hydrophobicity increases the NPC passage [62]. Efflux and influx rates can also be measured using the GFP-NLS and GFP-NES reporters by inhibiting active import or export and following the subsequent loss of compartmentalisation. Import and export rates are derived from experiments where the import or export of GFP-NLS or GFP-NES reporters is temporarily disturbed, after which the re-establishment of the equilibrium can be quantified. Jointly, this collection of assays reports on the steady state ratios between nuclear entry and exit, or yields the individual rates of entry and exit by temporarily altering the steady state.

There are several options to block import or export. CRM1 export can be inhibited by Leptomicin B (LMB) [63], a fungicide that binds CRM1 irreversibly in the NES binding region, thus blocking the binding between CRM1 and its cargo [64,65]. A limitation of the use of LMB may be its off-target effects; it also inhibits the degradation of p53 and upregulates apoptosis in cancer lines [66], limits RNA translation [67], and leads to accumulation of poly(A) ${ }^{+}$RNA within the nucleus [68]. Several import inhibitors are available that each block a specific transport route; e.g., importazole [69], ivermectin [70], and free importin- $\beta$-binding domain [50] inhibit the importin- $\alpha / \beta$ route, while the M9M peptide inhibits TNPO1 [71]. Alternatively, 2-deoxyglucose and/or sodium azide deplete cells from ATP, and can thus also be used to disrupt the RanGTP gradient. Depleting RanGTP inhibits major export and import pathways, but the different export routes are more sensitive to RanGTP depletion than the import via importin- $\alpha$, importin- $\beta$, or transportin [72]. Especially in baker's yeast, inhibition of import has been accomplished by anchor away strategies, such as anchoring of Kap95 to the plasma membrane ATPase using rapamycin inducible dimerization of FRB- and FKBP-domains attached to the NTR and the plasma membrane ATPase [73]. Methods that are performed at steady state and circumvent the use of drugs or poisons are based on fluorescence recovery after photobleaching (FRAP) and fluorescence loss in photobleaching (FLIP). In import studies, the nuclear area is bleached, and the recovery of nuclear fluorescence, which relies on the exchange of fluorescent molecules from the cytosol with bleached molecules from the nuclear compartments, is taken as a read-out for import rates [74,75]. As all assays, except those based on FRAP and FLIP, are subject to possible side effects of the interventions inhibiting transport, a combination of interventions is advisable.

Commonly used nucleocytoplasmic transport assays are performed in permeabilized cells, in live cells, or in in vitro assembled oocyte nuclei, and are listed in Table 2. A much used in vitro NCT assay uses digitonin permeabilized cells supplemented with exogenous recombinant transport factors [76]. This assay yields nuclei with functional NPCs 
while allowing to introduce the reporter proteins and NTRs at known concentrations and timepoints. The disadvantages are that permeabilization can relocate or extract soluble proteins [77] including transport factors and ATP [76], and potentially alter transport kinetics. In order to limit method artefacts, permeabilization assays are preferably combined with live-cell imaging [77]. The simplest transport measurements in live cells are those that determine the steady state distribution of GFP-NLS or GFP-NES reporters. Alternatively, as discussed above, the kinetics can be determined either based on the use of poisons to alter the steady state, or based on FRAP or FLIM. Lastly, like permeabilized cells, in vitro assembled oocyte nuclei also provide a system where reporter proteins and NTRs can be introduced at known concentrations and timepoints aiding kinetic measurements. Xenopus egg extracts contain the structural components of nuclei in a disassembled state, but will reconstitute nucleus-like structures around added DNA [78]. These nuclei actively exclude nonnuclear proteins and accumulate nucleoplasmin and proteins with NLSs [79-81], and import can be inhibited with lectin wheat germ agglutin, which binds to glycosylated FGNups [82]. Here, a combination of transport models may also provide the best assessment of the question at hand.

Table 2. Benefits and drawbacks of commonly used transport assays.
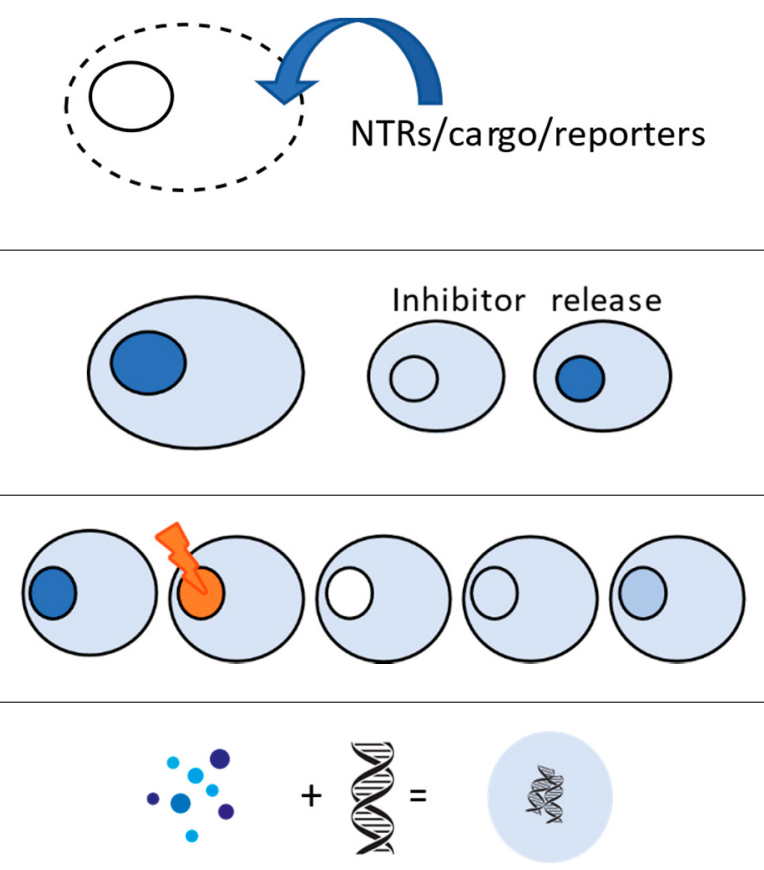

Cell permeabilization

+ Allows addition of specific concentration of cargo/NTR $[76,83]$

- Permeabilization can relocate or extract soluble proteins [77] including transport factors/ATP [76]; might deplete NTRs from NPCs; and reduces concentrations of competitive cargo, which increases import rates [84]

In vivo $\mathrm{N} / \mathrm{C}$ ratios; use of inhibitors

$+\mathrm{N} / \mathrm{C}$ ratio is a robust read-out largely independent of reporter levels [85]

- Expression/injection of reporter might be toxic; use of inhibitors to measure rates of nuclear entry and exit might be toxic

In vivo FRAP/FLIP

+ Direct measurement of kinetics of nuclear entry and exit; area under the curve indicates mobile fraction of the reporter - Expression/injection of reporter might be toxic; photobleaching induces ROS

Xenopus egg extracts

+ Proteins can be added to/immunodepleted from the extract - No native cytosolic fraction

-Allows studying nuclear pore complex assembly, function [86], transport [87,88], and cargo competition [89].

\section{Nuclear Transport Up-Close: Complications When Interpreting Nuclear Transport Data}

NCT assays rely on monitoring the localization of proteins to either the nuclear or cytosolic compartment (Figure 1). A change in localization can report a change in import or export efficiency by the joint action of NPCs, NTRs, and Ran. The interpretation of what drives the change in import or export efficiency and the contribution of each specific component (NPCs, NTRs or Ran), however, is often complicated for a number of reasons.

First, cargoes are transported by dedicated transporters, which recognize their cargo via particular NLSs and/or NESs. However, often, a simple "one cargo-one NTR" relation does not exist, as specific NTR-isoforms show preference for certain NLSs, several NTRs can be redundant for one specific NLS, and a protein or protein complex can contain multiple localization sequences (see Table 3 for examples). NLS sequences are, among others, the classical NLS, which has a mono- or bipartite basic amino acid cluster [90]; the 
PY-NLS; and a RG-rich NLS [91]. Some importins have their own preferred sequences, such as yeast Kap121, which recognizes a non-conventional lycine-rich sequence [92]. There is not yet a full overview in which sequences are recognized by the importins, but attempts are ongoing to discover more NLSs [93]. The full complement of interactions between NTRs and cargoes in a specific cellular setting has not been established to date, hence a change in localization of one cargo cannot easily be connected to the activity of a specific NTR or NTR isoform.

Second, import rates depend on the availability of the NTRs $[84,94,95]$. The formation of a complex of NTR and cargo in the crowded cytosol is rate-limiting compared with the fast translocation through the NPC, which is reported to occur on the timescale of milliseconds for commonly used reporters [96]. Therefore, altering the concentration of NTRs impacts transport rates. For example, Kap121 and Kap123 recognize the same NLSs, and when expressed at similar concentrations, import rates are indistinguishable [84]. However, natively, the abundance of Kap123 is higher than that of Kap121, thus making Kap123mediated import faster [84]. Import rates eventually saturate at high NTR levels, which must be owing to saturation of the NPCs, the RanGTP transport complex dissociation, or both [84]. The expression or availability of NTRs can change under stress conditions. For example, the importin Hikeshi, which uses ATP to import Hsp70 to limit shock-induced damage, is specifically upregulated under heat stress [16]. Moreover, conditions of oxidative stress and heat shock lead to rapid accumulation of Imp $\alpha$ in the nucleus $[97,98]$, and arsenite stress accumulates Imp $\alpha$ in stress granules [99]. To explain a change in the localization of a reporter mechanistically, one would want to know whether the intervention, e.g., the introduction of DPRs or $\mathrm{G}_{4} \mathrm{C}_{2}$ DNA sequences, created a change in the levels of NTRs available for transport.

Table 3. Transport specificity and redundancy.

\begin{tabular}{|c|c|c|}
\hline \multicolumn{3}{|c|}{ I. Transport of Cargo Depends on a Localization Sequence that is Recognized by an NTR } \\
\hline \multicolumn{2}{|c|}{ NTR } & NLS/NES \\
\hline \multicolumn{2}{|l|}{$\operatorname{Imp} \alpha / \beta$} & $\begin{array}{l}\text { Sv40/cNLS: PKKKRKV [90] } \\
\text { cMyc: PAAKRVKLD [100,101] } \\
\text { Nucleoplasmin: KRPAATKKAGQAKKKK [102] }\end{array}$ \\
\hline \multicolumn{2}{|l|}{ TNPO1 } & $\begin{array}{l}\text { PY-NLS: R-X } 2-5-P Y \text { motif [103] } \\
\text { e.g., FUS: RG-rich } 46 \text { RQDRRERPY [104] }\end{array}$ \\
\hline \multicolumn{2}{|l|}{ Kap104 } & RG-rich motif [91] \\
\hline \multicolumn{2}{|l|}{ Kap121 } & Lycine-rich sequence [92] \\
\hline \multicolumn{3}{|c|}{ Attempts to discover more NLSs [93] } \\
\hline \multicolumn{2}{|l|}{ CRM1 } & $\begin{array}{l}\Phi-X_{2-3}-\Phi-x_{2}-3-\Phi-x-\Phi \text {; where } \Phi \text { is I, M, F, V, and mostly L }[105,106] \\
\text { PKI: e.g., MSLNELALKLAGLDI [58] } \\
\text { HIV-1 Rev: LQLPPLERLTL }\end{array}$ \\
\hline \multicolumn{3}{|c|}{ II. Redundancy in NTRs for One Type of NLS } \\
\hline $\begin{array}{l}\text { NTR1 } \\
\text { NTR2 }\end{array}$ & $\begin{array}{l}\text { NLSi-Cargo1 } \\
\text { NLSi-Cargo1 }\end{array}$ & $\begin{array}{l}\text { Different NTRs can recognize the same NLS, and thus transport the same } \\
\text { cargo; e.g., Trn1, Trn2A, and Trn2B all bind the PY-NLS, and transport FUS } \\
\text { [107]/HuR [108], as well as unique cargoes. }\end{array}$ \\
\hline $\begin{array}{l}\text { NTR1a } \\
\text { NTR1b }\end{array}$ & $\begin{array}{l}\text { NLSi-Cargo1 } \\
\text { NLSi-Cargo2 }\end{array}$ & $\begin{array}{l}\text { Different isoforms of one NTR may bind the same NLS, but transport other } \\
\text { cargoes; e.g., importin- } \alpha \text { isoforms bind the classical NLS, but, e.g., STAT1 is } \\
\text { bound by } \alpha 5 \text {, but not by } \alpha 1 \text { [109]. Importin- } \alpha 3 \text { only recognizes the NLS with } \\
\text { appropriate N-terminal flanking residues [110]. }\end{array}$ \\
\hline \multicolumn{3}{|c|}{ III. Redundancy in NTRs for One Type of Cargo } \\
\hline $\begin{array}{l}\text { NTR1 } \\
\text { NTR2 }\end{array}$ & $\begin{array}{l}\text { NLSi -Cargo1 } \\
\text { NLSii-Cargo1 }\end{array}$ & $\begin{array}{l}\text { A group of cargoes, with distinct NLSs, can be recognized by different NTRs; } \\
\text { e.g., Kap121 can substitute Kap123 for import of ribosomal proteins }[111,112]\end{array}$ \\
\hline
\end{tabular}


Table 3. Cont.

\begin{tabular}{|c|c|c|}
\hline \multicolumn{3}{|c|}{ IV. Combinations of Localization Sequences } \\
\hline NTR1 & NLSi-NLSii-Cargo1 & One cargo may have two different NLSs; e.g., Nxf1 contains a cNLS for \\
\hline NTR2 & NLSi-NLSii-Cargo1 & importin $4 / 11 / \alpha / \beta$ and a PY-NLS for Trn1/Trn2 [113-117]. \\
\hline NTR1 & NLS-NES-Cargo1 & One cargo may contain an NLS and an NES; cyclin B $[118,119]$ and HIV Rev \\
\hline NTR2 & NLS-NES-Cargo1 & {$[105,120]$ contain an imp $\beta 1$ NLS and a CRM1 NES. } \\
\hline NTR1 & NES-adaptor & $\begin{array}{l}\text { Ribosomal pre60S particles bind to an adaptor protein (NMD3), which contains } \\
\text { the NES }[121,122] \text {. }\end{array}$ \\
\hline
\end{tabular}

Third, import rates also depend on the affinity between NTR and NLS, where over a certain range, a higher affinity will give a higher import rate $[84,85,123]$. However, a too high binding affinity prevents NTR-cargo complex dissociation and, consequently, inhibits transport $[124,125]$. Affinities can be temporarily altered by post-translational modifications (PTM), with phosphorylation of NTRs [126,127] and NLSs [128,129], the most studied PTM regulating NCT [130,131]. For example, transcription factors are only required for short periods of time and in small amounts, and sequences close to their NLS are phosphorylated to increase the affinity for importins $[128,129]$ or cause retention in nucleus or cytoplasm [132]. However, methylation [133,134], ubiquitination [135-137], acetylation [138], and sumoylation [139] have also been shown to influence NTR binding. NTR binding can also be altered by physicochemical parameters, as is the case for ROSinduced formation of disulfide bonds between TRN1 and FOXO [140], which is reversed in the more reduced environment of the nucleus [141]. Proteolytic events can unmask NLS and NES sequences [142-144], whereas binding to another protein [145-147] or mRNA [148], or protein multimerization $[149,150]$, can bury sorting sequences. To explain a change in the localization of a reporter mechanistically, one would want to know whether the affinity of the NTR for the NLS is altered. This is often not trivial to determine as the affinities determined with purified protein can be different from those determined in cytoplasmic extract [151] or those observed when multiple cargoes are presented simultaneously [152].

A fourth, and major, complication to interpret what drives the change in import or export efficiency is related to the fact that nuclear import of a specific heterologously expressed transport reporter (Figure 1) is always in competition with the transport of native cargoes. Because most NTRs have more than one specific cargo to transport, an increase in any of the cargoes of that NTR leads to lower N/C ratios of all its cargoes, including the reporter used to study transport $[75,89]$. Additionally, more cargo for one NTR can limit RanGTP availability to all NTRs, and slow down the recycling of importins and export. These aspects are easily overlooked when interpreting NCT data, but can lead to the false conclusion that the import kinetics by one specific NTR is reduced in a disease model compared with a wild type situation, while all that is changing is the concentration of competing cargo.

Lastly, it should be taken into account that changes in the localization of a reporter can be the result of changes to the NPCs themselves, both in number and in functionality. Recently, a disease-related reduced nuclear abundance of key Nups was shown in C9ALS and sporadic ALS iPSNs [153]. Theoretical considerations predict that fewer NPCs will support a higher accumulation of a GFP-NLS reporter in the nucleus [154], as the number of NPCs is likely limiting for efflux, but not for import $[84,89]$. Additionally, the deletion of one nucleoporin immediately translates to reduced export [155-161], but because the rate limiting step for import is receptor binding [95,154,162], cells still maintain high import rates even when FG-domains in the NPCs are deleted $[6,163]$. Specific NTRs preferentially bind specific FG-Nups, hence the presence or absence of certain FG-Nups may affect only specific import routes $[6,164,165]$. PTM has been reported to change the structure of pores. For example, in yeast, phosphorylation of Nup53 releases its binding partner Nup170, thus exposing binding sites for Kap121 on Nup170, limiting Kap121 import directly [166], a process that may also underlie reduced transport by TRN-1 and Kap $\beta$ [127]. Knowing the number and functionality of individual NPCs is a major challenge, and together with 
the previously mentioned complications of mapping the full complement of NTRS and cognate cargoes in a cell, these aspects provide the largest challenge in interpreting what underlies a change in the localization of a NCT reporter.

To summarize, in order to assess if the transport of proteins is altered in a disease model, well controlled steady state, or dynamic measurements of the location of mobile, non-toxic reporter proteins suffice. Preferably, multiple NLS- or NES-containing reporters representing different transport pathways are used. To understand what drives a possible change in the transport of these reporters, several additional, and rather complex, questions have to be addressed (summarized in Figure 2). In case of the outermost layers, we enter into what is presently still largely uncharted scientific territory.

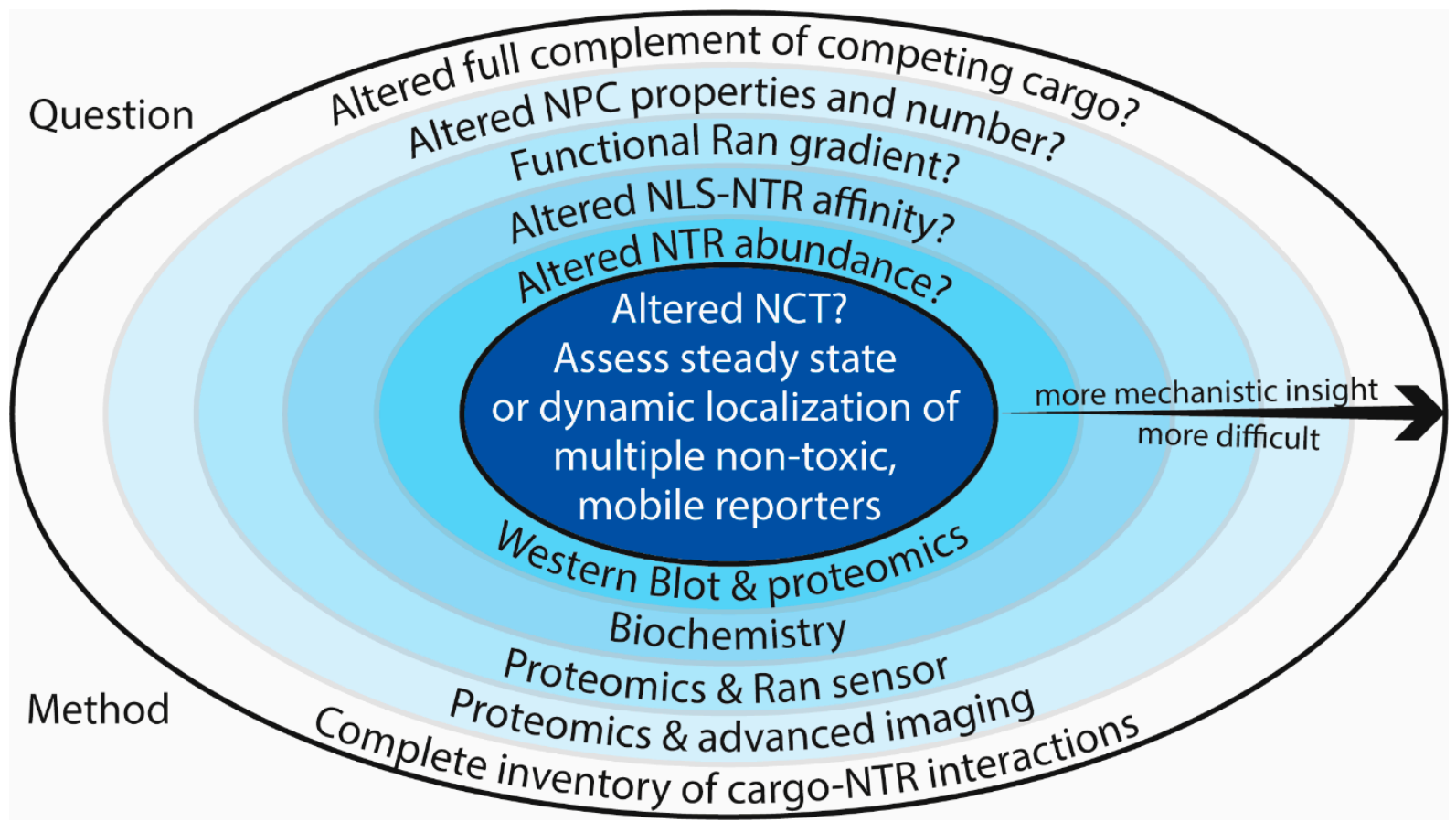

Figure 2. An overview of the questions related to answering whether nucleocytoplasmic transport is altered in a disease model; questions are shown in the top half of the image and methods are shown in the bottom half. The centre circle represents the main question of whether or not NCT is altered; this question can be answered by comparing the localization of transport reporters to either the nuclear or cytosolic compartment in wild type and disease models. The reporters have to be non-toxic, mobile, and preferably multiple NLS- or NES-containing reporters representing different transport pathways are used. To answer how NCT is altered, different additional questions have to be answered represented in layers of increasing complexity. In the case of the outermost layers, we enter into what is presently still largely uncharted scientific territory.

All considerations above apply when comparing data obtained using different model systems. Nucleoporin expression changes between different cell types, tissues, and diseasestates [167-171], as well as during development and ageing [172,173]. Moreover, the abundance of the NTRs differs between cell types. For example, Kap $\alpha$ levels differ between leukaemic cell lines [151] and between testis, ovary, spleen, heart, kidney, brain, or muscle cells [152,174-177]. Further, whereas TRN2A is expressed in HeLa cells, it is undetectable in HEK293T cells [108]. Kap $\alpha 2$ [178-182] and CRM1 [182-189] have been shown to be upregulated in different types of cancers, and NTR expression is regulated during development $[190,191]$ and differentiation $[192,193]$. Thus, there is cell type variability of NPCs and cognate nuclear transport factors, which complicates the comparison of results from different studies.

For the studies related to C9-ALS, a further complication in the comparison of results is related to the fact that the DPRs impact cell physiology variably in the used biological systems as they localize differently and are toxic to different extents. In Table 4, we 
summarize the localization of different DPRs in different model systems and highlight whether they convey growth defects (indicated in different colours). For example, polyPR is generally the most toxic DPR and PA is often non-toxic; this is the case in PPSC neurons [194], S. cerevisiae [47], rat neurons [194], mouse neurons, and HEK293 cells [195]. Yet, in zebrafish embryos, PR is less toxic than GR and equally toxic to PA [196]. PR is rarely found in patient material, usually attributed to its high toxicity, but if it is detected, it is found in aggregates in the cytoplasm [197,198]. This localization is not observed in most model systems where PR is nuclear or nucleolar [194,195,199-202]. The reports on poly-GA are diverse, reporting non-toxic $[46,47,53,194-196,199,200,203,204]$ as well as toxic $[49,200,205,206]$ effects. Interestingly, it seems that the toxicity of DRPs increases when cells are further differentiated into neurons [207]. Thus, even independent of the discussed cell type specific differences in the nuclear pores and cognate transport factors, the effect of DPRs on transport in the different C9-ALS models may be variable owing to differences in localization and toxicity.

\section{Is Nuclear Transport Altered in C9-ALS?}

The seven papers on NCT in C9-ALS [45,50,52,55,57-59] jointly report on 21 experiments assessing the localization of transport reporters in different C9-ALS models (Table 1). Clearly, despite obtaining solid and significant data, it is still difficult to conclude whether the data unambiguously establish that actual effects on NCT kinetics are observed when introducing C9-ALS-related peptides or DNA. How can six papers convincingly show alterations in the localization of transport reporters $[45,50,52,55,57,59]$, whereas the seventh extensively shows no effects can be observed [58]?

Cell type-specific characteristics. When discussing several complications in the interpretation of NCT data, we mentioned cell type-specific transport characteristics, such as distinct NLS-NTR affinities or NTR abundances. This complication is clear when comparing the outcomes of the experiments in $\mathrm{B}$ and $\mathrm{D}$ (Table 1, for all further references in this section, see Table 1); the same reporter that is excluded from the nucleus in wild type motor neurons localizes to the nucleus in wild type Drosophila salivary glands. The same is observed comparing wild type HeLa Kyoto cells (L) and neuronal cells (N), where the reporter localizes differently in both cell types. These differences depending on cell type are also observed when specific DPRs are introduced. Namely, $\mathrm{PR}_{20}$ peptide injection reduces importin- $\alpha / \beta$ import in U2OS cells (F), but not in HeLa Kyoto cells (J). Similarly, poly-GA impacts the transport of an $\mathrm{NLS}_{\mathrm{Sv} 40}-$ mNeonGreen $_{2 \mathrm{x}}-\mathrm{NES}_{\mathrm{PKI}}$ reporter in neuronal cells $(\mathrm{N})$, but not in HeLa Kyoto cells (L). There may even be subpopulations within a cell type that behave differently. For example, when a subpopulation of cells with stress granules is selected, transport alterations are observed for (L), whereas this was not seen in the whole population [58]. This may be linked to the fact that arginine-rich DPRs can undergo liquid-liquid phase separation, and induce phase separation of a large set of proteins involved in RNA and stress granule metabolism [208]. Jointly, the cell type-specific localization of a reporter in wild type cells illustrates that cell type-specific differences in, among others, NPCs and cognate transport factors impact the transport assays (Table 1, compare L-N, B-D). In addition, the introduction of C9-ALS models adds to the variability between cell types (Table 1, compare F-J, N-L), possibly through the mentioned differences in localization and toxicity (Table 4 ).

Sorting signals. When discussing the different transport assays available, their possible technical complications were mentioned. A potential issue when using reporters with multiple localization signals relates to the fact that GFP has an intrinsic tendency to accumulate in the nuclear compartment [62,209], irrespective of the presence of an NLS. Nuclear localization of a GFP-based reporter may thus not be driven by import, but rather by influx. For example, the data suggest that the Sv40NLS is not very effective in motor neurons, as it does not promote nuclear accumulation when the NES is removed (E). Without controls, we do not know whether the nuclear accumulation of a reporter is due to import or influx, and the impact of DPRs thus might be on influx rather than active 
transport. Determining the effect is complicated, as Hayes et al. show that passive diffusion of GFP and small fluorescent dextrans into the nucleus, and thus influx of molecules is increased by $\mathrm{PR}_{10}$ and $\mathrm{GR}_{10}$ [50]. Validating the functionality of the sorting signals in reporters with both NLS and NES sequences is thus important to prevent changes in influx being misinterpreted as changes in import.

Transport assays. Changes in transport induced by the introduction of C9-ALS models are quantified in different ways, reporting either the nuclear fluorescence or the cytosolic fluorescence $(A-G)$ or a ratio relative to the total $(H-N)$ or cytosolic $(\mathrm{O}-\mathrm{P})$ fluorescence. Measuring the steady state fluorescence in the nucleus relative to the cytosol or total fluorescence is less sensitive to changes in expression level than other readouts such as nuclear (or cytosol) fluorescence alone. This may have impacted the interpretation in this case as poly-PR (and poly-GR) can limit translation [58,204,210]. Hence, it is possible that the expression of the reporter is reduced in the C9-ALS-models $(B, C)$, which caused a lower nuclear fluorescence, rather than an effect on import.

Mobile reporters are the basis of all transport assays, and a quantification of the mobile fraction in FRAP experiments can be used to confirm that they are indeed mobile. However, it is the rate of recovery after bleaching in the nuclear or cytosolic compartment that is a measure for the kinetics of transport. The experiment in (A), for example, measures the change in mobile fraction, rather than actual transport kinetics.

Regarding the choice of transport assays (Table 2) and reporter, we mentioned that it is preferable to assess different transport reporters when studying NCT, as different NTRs each represent unique import pathways with unique parameters-affinities for FGNups, expression levels, and competing cargoes_defining their import kinetics. This is illustrated in $(\mathrm{H}, \mathrm{I})$ where the localization of a TNPO1 cargo is insensitive to $\mathrm{GA}_{149}$, while that of an importin- $\alpha / \beta$ is sensitive. Moreover, each transport assay has advantages and disadvantages (Table 2), and even though cell permeabilization assays $(G)$ and injections $(\mathrm{F}, \mathrm{G}, \mathrm{J}, \mathrm{K})$ are used frequently in the field, it would be helpful to combine permeabilized studies with live-cell imaging.

Jointly, in the case of these C9-ALS studies, several technical limitations may have impacted the interpretation of the data summarized in Table 1. Hence, at present, it is not firmly established whether the introduction of disease-related biomolecules, G4C2-DNA, RNA, and DPRs, impacts the transport kinetics by NPCs.

Thus, even though convincing data have been obtained confirming a relation to the NCT machinery in C9-ALS in general, it is difficult to conclude from the current transport data if and how C9-ALS affects the actual kinetics of NCT. For future studies, the choice of model systems is critical, both from the perspective of the diverse behaviour of C9-ALS related DPRs (Table 4) and the diversity in the characteristics of NCT in different cells types. Moreover, to facilitate the interpretation of transport assays mechanistically, one would ideally quantify all nucleocytoplasmic transport components (NTR abundance, NPC number and functionality, and the integrity of the Ran gradient), study different NTRs, and combine different transport assays. These in-depth studies are required to answer whether NCT is changed in C9-ALS, and potentially many proteins are mislocalized, leading to cellular alterations causing the disease, or, alternatively, that the NCT machinery is a robust system, and widespread mislocalization of nuclear proteins should not be expected to occur or be causal to the phenotype of C9-ALS. The challenges described are not unique to the case of C9-ALS, and answering the question of how NCT is impacted in neurodegenerative diseases represents a major opportunity for scientists from the nuclear transport and neuroscience communities. 
Table 4. Toxicity and cellular localization of DPRs are not the same in all studied model organisms.

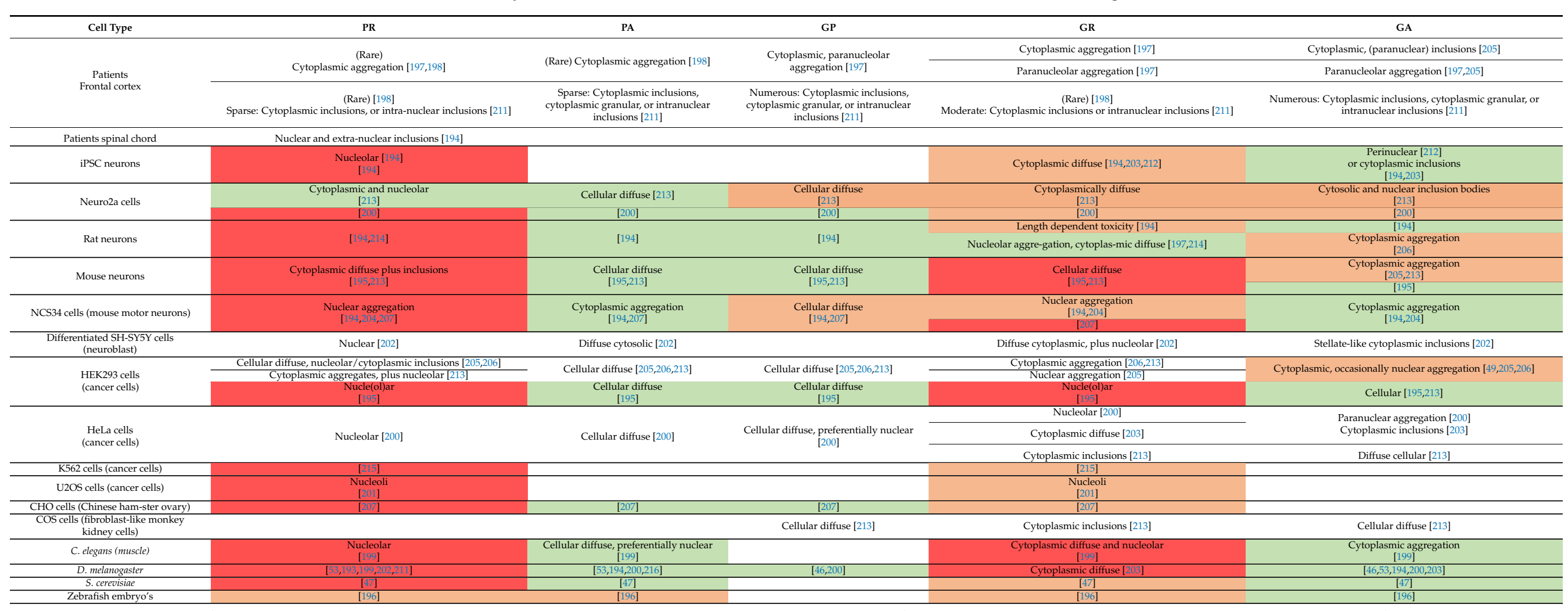

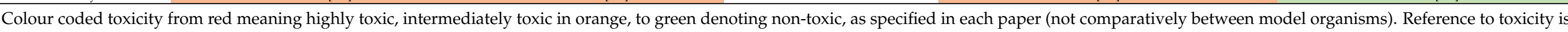
in the right lower corner. 
Author Contributions: This review was written by M.F.W.S. with input from A.S. and L.M.V. All authors have read and agreed to the published version of the manuscript.

Funding: This work was financially supported by the Netherlands Organization for Scientific Research (NWO BBOL 737.016.016 to L.M.V.).

Institutional Review Board Statement: Not applicable.

Informed Consent Statement: Not applicable.

Conflicts of Interest: The authors declare no conflict of interest.

$\begin{array}{ll}\text { Abbreviations } & \\ \text { ALS } & \text { amyotrophic lateral sclerosis } \\ \text { C9-ALS } & \text { C9orf72-related ALS } \\ \text { DPRs } & \text { dipeptide repeat proteins } \\ \text { FGenylalanine glycine repeat } \\ \text { FLIP } & \text { fluorescence loss in photobleaching } \\ \text { FRAP } & \text { fluorescence recovery after photobleaching } \\ \text { FUS } & \text { fused in sarcoma } \\ \text { GA, GP, GR, PA, PR } & \text { glycine-alanine, glycine-proline, glycine-arginine, proline-alanine, } \\ & \text { proline-arginine repeats } \\ \text { LMB } & \text { leptomycin B } \\ \text { NES } & \text { nuclear export sequence } \\ \text { NLS } & \text { nuclear localization sequence } \\ \text { NP/NMP1 } & \text { nucleophosmin } \\ \text { NPC } & \text { nuclear pore complex } \\ \text { NTR } & \text { nuclear transport receptor } \\ \text { Nups } & \text { nucleoporins } \\ \text { PKI } & \text { cAMP-dependent protein kinase inhibitor } \\ \text { PTM } & \text { post-translational modification } \\ \text { RAN translation } & \text { repeat-associated non-AUG translation } \\ \text { Ran } & \text { Ras-related nuclear protein } \\ \text { RanGAP } & \text { Ran GTPase activating protein } \\ \text { RanGEF } & \text { Ran guanine nucleotide exchange factorRBP RNA binding protein } \\ \text { ROS } & \text { reactive oxygen species } \\ \text { Sv40 } & \text { simian virus 40 } \\ \text { Rev } & \text { human immunodeficiency virus type 1 Rev protein } \\ \text { TDP-43 } & \text { TAR-DNA binding protein 43 } \\ \text { TNPO1 } & \text { Kap } 32 \\ \text { TRN1 } & \text { transportin 1 } \\ & \end{array}$

\section{References}

1. Popken, P.; Ghavami, A.; Onck, P.R.; Poolman, B.; Veenhoff, L.M. Size-dependent leak of soluble and membrane proteins through the yeast nuclear pore complex. Mol. Biol. Cell 2015, 26, 1386-1394. [CrossRef]

2. Timney, B.L.; Raveh, B.; Mironska, R.; Trivedi, J.M.; Kim, S.J.; Russel, D.; Wente, S.R.; Sali, A.; Rout, M.P. Simple rules for passive diffusion through the nuclear pore complex. J. Cell Biol. 2016, 215, 57-76. [CrossRef]

3. Rout, M.P.; Aitchison, J.D.; Suprapto, A.; Hjertaas, K.; Zhao, Y.; Chait, B.T. The Yeast Nuclear Pore Complex. J. Cell Biol. 2000, 148 , 635-652. [CrossRef]

4. Cronshaw, J.M.; Krutchinsky, A.N.; Zhang, W.; Chait, B.T.; Matunis, M.J. Proteomic analysis of the mammalian nuclear pore complex. J. Cell Biol. 2002, 158, 915-927. [CrossRef] [PubMed]

5. Terry, L.J.; Wente, S.R. Nuclear mRNA export requires specific FG nucleoporins for translocation through the nuclear pore complex. J. Cell Biol. 2007, 178, 1121-1132. [CrossRef]

6. Strawn, L.A.; Shen, T.; Shulga, N.; Goldfarb, D.S.; Wente, S.R. Minimal nuclear pore complexes define FG repeat domains essential for transport. Nat. Cell Biol. 2004, 6, 197-206. [CrossRef]

7. Marg, A.; Shan, Y.; Meyer, T.; Meissner, T.; Brandenburg, M.; Vinkemeier, U. Nucleocytoplasmic shuttling by nucleoporins Nup153 and Nup214 and CRM1-dependent nuclear export control the subcellular distribution of latent Stat1. J. Cell Biol. 2004, 165, 823-833. [CrossRef] [PubMed] 
8. Allen, N.P.; Huang, L.; Burlingame, A.; Rexach, M. Proteomic Analysis of Nucleoporin Interacting Proteins. J. Biol. Chem. 2001, 276, 29268-29274. [CrossRef]

9. Dilworth, D.J.; Suprapto, A.; Padovan, J.C.; Chait, B.T.; Wozniak, R.W.; Rout, M.; Aitchison, J.D. Nup2p Dynamically Associates with the Distal Regions of the Yeast Nuclear Pore Complex. J. Cell Biol. 2001, 153, 1465-1478. [CrossRef] [PubMed]

10. Marelli, M.; Aitchison, J.D.; Wozniak, R.W. Specific Binding of the Karyopherin Kap121p to a Subunit of the Nuclear Pore Complex Containing Nup53p, Nup59p, and Nup170p. J. Cell Biol. 1998, 143, 1813-1830. [CrossRef] [PubMed]

11. Lowe, A.R.; Tang, J.H.; Yassif, J.; Graf, M.; Huang, W.Y.C.; Groves, J.T.; Weis, K.; Liphardt, J.T. Importin- $\beta$ modulates the permeability of the nuclear pore complex in a Ran-dependent manner. eLife 2015, 4, e04052. [CrossRef]

12. Galy, V.; Gadal, O.; Fromont-Racine, M.; Romano, A.; Jacquier, A.; Nehrbass, U. Nuclear Retention of Unspliced mRNAs in Yeast Is Mediated by Perinuclear Mlp1. Cell 2004, 116, 63-73. [CrossRef]

13. Wozniak, R.W.; Rout, M.P.; Aitchison, J.D. Karyopherins and kissing cousins. Trends Cell Biol. 1998, 8, 184-188. [CrossRef]

14. Titov, A.A.; Blobel, G. The Karyopherin Kap122p/Pdr6p Imports Both Subunits of the Transcription Factor Iia into the Nucleus. J. Cell Biol. 1999, 147, 235-246. [CrossRef] [PubMed]

15. Allen, N.P.; Patel, S.S.; Huang, L.; Chalkley, R.; Burlingame, A.; Lutzmann, M.; Hurt, E.C.; Rexach, M. Deciphering Networks of Protein Interactions at the Nuclear Pore Complex. Mol. Cell. Proteom. 2002, 1, 930-946. [CrossRef]

16. Kose, S.; Furuta, M.; Imamoto, N. Hikeshi, a Nuclear Import Carrier for Hsp70s, Protects Cells from Heat Shock-Induced Nuclear Damage. Cell 2012, 149, 578-589. [CrossRef] [PubMed]

17. Kosyna, F.K.; Depping, R. Controlling the Gatekeeper: Therapeutic Targeting of Nuclear Transport. Cells 2018, 7, 221. [CrossRef]

18. Baade, I.; Kehlenbach, R.H. The cargo spectrum of nuclear transport receptors. Curr. Opin. Cell Biol. 2019, 58, 1-7. [CrossRef]

19. Pumroy, R.A.; Cingolani, G. Diversification of Importin- $\alpha$ Isoforms in Cellular Trafficking and Disease States. Biochem. J. 2015, 466, 13-28. [CrossRef]

20. Yao, W.; Lutzmann, M.; Hurt, E. A versatile interaction platform on the Mex67-Mtr2 receptor creates an overlap between mRNA and ribosome export. EMBO J. 2007, 27, 6-16. [CrossRef]

21. Kutay, U.; Bischoff, F.; Kostka, S.; Kraft, R.; Görlich, D. Export of Importin $\alpha$ from the Nucleus Is Mediated by a Specific Nuclear Transport Factor. Cell 1997, 90, 1061-1071. [CrossRef]

22. Bischoff, F.; Görlich, D. RanBP1 is crucial for the release of RanGTP from importin $\beta$-related nuclear transport factors. FEBS Lett. 1997, 419, 249-254. [CrossRef]

23. Cautain, B.; Hill, R.; De Pedro, N.; Link, W. Components and regulation of nuclear transport processes. FEBS J. 2014, $282,445-462$. [CrossRef] [PubMed]

24. Lolodi, O.; Yamazaki, H.; Otsuka, S.; Kumeta, M.; Yoshimura, S.H. Dissecting in vivo steady-state dynamics of karyopherindependent nuclear transport. Mol. Biol. Cell 2016, 27, 167-176. [CrossRef]

25. Taylor, J.P.; Brown, R.H., Jr.; Cleveland, D.W. Decoding ALS: From genes to mechanism. Nature 2016, 539, 197-206. [CrossRef]

26. Kiernan, M.C.; Vucic, S.; Cheah, B.C.; Turner, M.; Eisen, A.; Hardiman, O.; Burrell, J.; Zoing, M.C. Amyotrophic lateral sclerosis. Lancet 2011, 377, 942-955. [CrossRef]

27. Renton, A.E.; Chio, A.; Traynor, B.J. State of play in amyotrophic lateral sclerosis genetics. Nat. Neurosci. 2014, 17, 17-23. [CrossRef]

28. Renton, A.E.; Majounie, E.; Waite, A.; Sánchez, J.S.; Rollinson, S.; Gibbs, J.R.; Schymick, J.C.; Laaksovirta, H.; van Swieten, J.C.; Myllykangas, L.; et al. A Hexanucleotide Repeat Expansion in C9ORF72 Is the Cause of Chromosome 9p21-Linked ALS-FTD. Neuron 2011, 72, 257-268. [CrossRef] [PubMed]

29. DeJesus-Hernandez, M.; Mackenzie, I.R.; Boeve, B.F.; Boxer, A.L.; Baker, M.; Rutherford, N.J.; Nicholson, A.M.; Finch, N.A.; Flynn, H.; Adamson, J.; et al. Expanded GGGGCC Hexanucleotide Repeat in Noncoding Region of C9ORF72 Causes Chromosome 9p-Linked FTD and ALS. Neuron 2011, 72, 245-256. [CrossRef]

30. Green, K.M.; Linsalata, A.E.; Todd, P.K. RAN translation-What makes it run? Brain Res. 2016, 1647, 30-42. [CrossRef] [PubMed]

31. Ash, P.E.; Bieniek, K.; Gendron, T.F.; Caulfield, T.; Lin, W.-L.; DeJesus-Hernandez, M.; van Blitterswijk, M.; Jansen-West, K.; Paul, J.W.; Rademakers, R.; et al. Unconventional Translation of C9ORF72 GGGGCC Expansion Generates Insoluble Polypeptides Specific to c9FTD/ALS. Neuron 2013, 77, 639-646. [CrossRef] [PubMed]

32. Mori, K.; Weng, S.-M.; Arzberger, T.; May, S.; Rentzsch, K.; Kremmer, E.; Schmid, B.; Kretzschmar, H.A.; Cruts, M.; Van Broeckhoven, C.; et al. The C9orf72 GGGGCC Repeat Is Translated into Aggregating Dipeptide-Repeat Proteins in FTLD/ALS. Science 2013, 339, 1335-1338. [CrossRef] [PubMed]

33. Patel, V.P.; Chu, C. Nuclear transport, oxidative stress, and neurodegeneration. Int. J. Clin. Exp. Pathol. 2011, 4, 215-229. [PubMed]

34. Loureiro, J.; Oliveira, C.; Silveira, I. Unstable repeat expansions in neurodegenerative diseases: Nucleocytoplasmic transport emerges on the scene. Neurobiol. Aging 2016, 39, 174-183. [CrossRef] [PubMed]

35. Kim, H.J.; Taylor, J.P. Lost in Transportation: Nucleocytoplasmic Transport Defects in ALS and Other Neurodegenerative Diseases. Neuron 2017, 96, 285-297. [CrossRef] [PubMed]

36. Li, N.; Lagier-Tourenne, C. Nuclear pores: The gate to neurodegeneration. Nat. Neurosci. 2018, 21, 156-158. [CrossRef]

37. Ferreira, P.A. The coming-of-age of nucleocytoplasmic transport in motor neuron disease and neurodegeneration. Cell. Mol. Life Sci. 2019, 76, 2247-2273. [CrossRef] [PubMed]

38. Benarroch, E.E. Nucleocytoplasmic transport. Neurology 2019, 92, 757-764. [CrossRef] 
39. Hutten, S.; Dormann, D. Nucleocytoplasmic Transport Defects in Neurodegeneration-Cause or Consequence? Semin. Cell Dev. Biol. 2019, 99, 151-162. [CrossRef]

40. Bitetto, G.; Di Fonzo, A. Nucleo-cytoplasmic transport defects and protein aggregates in neurodegeneration. Transl. Neurodegener. 2020, 9, 1-16. [CrossRef]

41. Fallini, C.; Khalil, B.; Smith, C.L.; Rossoll, W. Traffic jam at the nuclear pore: All roads lead to nucleocytoplasmic transport defects in ALS/FTD. Neurobiol. Dis. 2020, 140, 104835. [CrossRef] [PubMed]

42. Diez, L.; Wegmann, S. Nuclear Transport Deficits in Tau-Related Neurodegenerative Diseases. Front. Neurol. 2020, 11, 11. [CrossRef] [PubMed]

43. Hachiya, N.; Sochocka, M.; Brzecka, A.; Shimizu, T.; Gasiorowski, K.; Szczechowiak, K.; Leszek, J. Nuclear Envelope and Nuclear Pore Complexes in Neurodegenerative Diseases-New Perspectives for Therapeutic Interventions. Mol. Neurobiol. 2021, 58, 983-995. [CrossRef]

44. Xiao, S.; Macnair, L.; McGoldrick, P.; McKeever, P.M.; McLean, J.R.; Zhang, M.; Keith, J.; Zinman, L.; Rogaeva, E.; Robertson, J. Isoform-specific antibodies reveal distinct subcellular localizations of C 9 orf72 in amyotrophic lateral sclerosis. Ann. Neurol. 2015, 78, 568-583. [CrossRef]

45. Zhang, K.; Donnelly, C.J.; Haeusler, A.R.; Grima, J.C.; Machamer, J.B.; Steinwald, P.; Daley, E.; Miller, S.J.; Cunningham, K.; Vidensky, S.; et al. The C9orf72 repeat expansion disrupts nucleocytoplasmic transport. Nat. Cell Biol. 2015, 525, 56-61. [CrossRef]

46. Freibaum, B.D.; Lu, Y.; Lopez-Gonzalez, R.; Kim, N.C.; Almeida, S.; Lee, K.-H.; Badders, N.; Valentine, M.; Miller, B.L.; Wong, P.C.; et al. GGGGCC repeat expansion in C9orf72 compromises nucleocytoplasmic transport. Nat. Cell Biol. 2015, 525, 129-133. [CrossRef]

47. Jovičić, A.; Mertens, J.; Boeynaems, S.; Bogaert, E.; Chai, N.; Yamada, S.B.; Paul, J.W.; Sun, S.; Herdy, J.R.; Bieri, G.; et al. Modifiers of C9orf72 dipeptide repeat toxicity connect nucleocytoplasmic transport defects to FTD/ALS. Nat. Neurosci. 2015, 18, 1226-1229. [CrossRef]

48. Vanneste, J.; Van Den Bosch, L. The Role of Nucleocytoplasmic Transport Defects in Amyotrophic Lateral Sclerosis. Int. J. Mol. Sci. 2021, in press.

49. Zhang, Y.-J.; Gendron, T.F.; Grima, J.C.; Sasaguri, H.; Jansen-West, K.; Xu, Y.-F.; Katzman, R.B.; Gass, J.; E Murray, M.; Shinohara, M.; et al. C9ORF72 poly(GA) aggregates sequester and impair HR23 and nucleocytoplasmic transport proteins. Nat. Neurosci. 2016, 19, 668-677. [CrossRef] [PubMed]

50. Hayes, L.R.; Duan, L.; Bowen, K.; Kalab, P.; Rothstein, J.D. C9orf72 arginine-rich dipeptide repeat proteins disrupt karyopherinmediated nuclear import. eLife 2020, 9, e51685. [CrossRef]

51. Kinoshita, Y.; Ito, H.; Hirano, A.; Fujita, K.; Wate, R.; Nakamura, M.; Kaneko, S.; Nakano, S.; Kusaka, H. Nuclear Contour Irregularity and Abnormal Transporter Protein Distribution in Anterior Horn Cells in Amyotrophic Lateral Sclerosis. J. Neuropathol. Exp. Neurol. 2009, 68, 1184-1192. [CrossRef] [PubMed]

52. Shi, K.Y.; Mori, E.; Nizami, Z.F.; Lin, Y.; Kato, M.; Xiang, S.; Wu, L.C.; Ding, M.; Yu, Y.; Gall, J.G.; et al. Toxic PRn poly-dipeptides encoded by the C9orf72 repeat expansion block nuclear import and export. Proc. Natl. Acad. Sci. USA. 2017, 114, E1111-E1117. [CrossRef] [PubMed]

53. Boeynaems, S.; Bogaert, E.; Michiels, E.; Gijselinck, I.; Sieben, A.; Jovičić, A.; De Baets, G.; Scheveneels, W.; Steyaert, J.; Cuijt, I.; et al. Drosophila screen connects nuclear transport genes to DPR pathology in c9ALS/FTD. Sci. Rep. 2016, 6, 20877. [CrossRef] [PubMed]

54. Saberi, S.; Stauffer, J.E.; Jiang, J.; Garcia, S.D.; Taylor, A.E.; Schulte, D.; Ohkubo, T.; Schloffman, C.L.; Maldonado, M.; Baughn, M.; et al. Sense-encoded poly-GR dipeptide repeat proteins correlate to neurodegeneration and uniquely co-localize with TDP-43 in dendrites of repeat-expanded C9orf72 amyotrophic lateral sclerosis. Acta Neuropathol. 2018, 135, 459-474. [CrossRef]

55. Chou, C.-C.; Zhang, Y.; Umoh, M.E.; Vaughan, S.W.; Lorenzini, I.; Liu, F.; Sayegh, M.; Donlin-Asp, P.; Chen, Y.H.; Duong, D.; et al. TDP-43 pathology disrupts nuclear pore complexes and nucleocytoplasmic transport in ALS/FTD. Nat. Neurosci. 2018, 21, 228-239. [CrossRef]

56. Solomon, D.A.; Stepto, A.; Au, W.H.; Adachi, Y.; Diaper, D.C.; Hall, R.; Rekhi, A.; Boudi, A.; Tziortzouda, P.; Lee, Y.; et al. A feedback loop between dipeptide-repeat protein, TDP-43 and karyopherin- $\alpha$ mediates C9orf72-related neurodegeneration. Brain 2018, 141, 2908-2924. [CrossRef]

57. Khosravi, B.; Hartmann, H.; May, S.; Möhl, C.; Ederle, H.; Michaelsen, M.; Schludi, M.H.; Dormann, D.; Edbauer, D. Cytoplasmic poly-GA aggregates impair nuclear import of TDP-43 in C9orf72 ALS/FTLD. Hum. Mol. Genet. 2016, 26, 790-800. [CrossRef]

58. Vanneste, J.; Vercruysse, T.; Boeynaems, S.; Sicart, A.; Van Damme, P.; Daelemans, D.; Bosch, L.V.D. C9orf72-generated poly-GR and poly-PR do not directly interfere with nucleocytoplasmic transport. Sci. Rep. 2019, 9, 1-10. [CrossRef]

59. Hutten, S.; Usluer, S.; Bourgeois, B.; Simonetti, F.; Odeh, H.M.; Fare, C.M.; Czuppa, M.; Hruska-Plochan, M.; Hofweber, M.; Polymenidou, M.; et al. Nuclear Import Receptors Directly Bind to Arginine-Rich Dipeptide Repeat Proteins and Suppress Their Pathological Interactions. Cell Rep. 2020, 33, 108538. [CrossRef]

60. Shulga, N.; Roberts, P.; Gu, Z.; Spit, L.; Tab, M.M.; Nomura, M.; Goldfarb, D.S. In vivo nuclear transport kinetics in Saccharomyces cerevisiae: A role for heat shock protein 70 during targeting and translocation. J. Cell Biol. 1996, 135, 329-339. [CrossRef]

61. Woerner, A.C.; Frottin, F.; Hornburg, D.; Feng, L.R.; Meissner, F.; Patra, M.; Tatzelt, J.; Mann, M.; Winklhofer, K.F.; Hartl, F.U.; et al. Cytoplasmic protein aggregates interfere with nucleocytoplasmic transport of protein and RNA. Science 2016, 351, 173-176. [CrossRef] [PubMed] 
62. Frey, S.; Rees, R.; Schünemann, J.; Ng, S.C.; Fünfgeld, K.; Huyton, T.; Görlich, D. Surface Properties Determining Passage Rates of Proteins through Nuclear Pores. Cell 2018, 174, 202-217e9. [CrossRef]

63. Fukuda, M.; Asano, S.; Nakamura, T.; Adachi, M.; Yoshida, M.; Yanagida, M.; Nishida, E. CRM1 is responsible for intracellular transport mediated by the nuclear export signal. Nat. Cell Biol. 1997, 390, 308-311. [CrossRef]

64. Nishi, K.; Yoshida, M.; Fujiwara, D.; Nishikawa, M.; Horinouchi, S.; Beppu, T. Leptomycin B targets a regulatory cascade of crm1, a fission yeast nuclear protein, involved in control of higher order chromosome structure and gene expression. J. Biol. Chem. 1994, 269, 6320-6324. [CrossRef]

65. Kudo, N.; Matsumori, N.; Taoka, H.; Fujiwara, D.; Schreiner, E.P.; Wolff, B.; Yoshida, M.; Horinouchi, S. Leptomycin B inactivates CRM1/exportin 1 by covalent modification at a cysteine residue in the central conserved region. Proc. Natl. Acad. Sci. USA 1999, 96, 9112-9117. [CrossRef] [PubMed]

66. Hietanen, S.; Lain, S.; Krausz, E.; Blattner, C.; Lane, D. Activation of p53 in cervical carcinoma cells by small molecules. Proc. Natl. Acad. Sci. USA 2000, 97, 8501-8506. [CrossRef] [PubMed]

67. Watanabe, K.; Takizawa, N.; Katoh, M.; Hoshida, K.; Kobayashi, N.; Nagata, K. Inhibition of nuclear export of ribonucleoprotein complexes of influenza virus by leptomycin B. Virus Res. 2001, 77, 31-42. [CrossRef]

68. Latonen, L.; Moore, H.M.; Bai, B.; Jäämaa, S.; Laiho, M. Proteasome inhibitors induce nucleolar aggregation of proteasome target proteins and polyadenylated RNA by altering ubiquitin availability. Oncogene 2010, 30, 790-805. [CrossRef]

69. Soderholm, J.F.; Bird, S.L.; Kalab, P.; Sampathkumar, Y.; Hasegawa, K.; Uehara-Bingen, M.; Weis, K.; Heald, R. Importazole, a Small Molecule Inhibitor of the Transport Receptor Importin- $\beta$. ACS Chem. Biol. 2011, 6, 700-708. [CrossRef]

70. Wagstaff, K.; Sivakumaran, H.; Heaton, S.; Harrich, D.; Jans, D. Ivermectin is a specific inhibitor of importin $\alpha / \beta-$ mediated nuclear import able to inhibit replication of HIV-1 and dengue virus. Biochem. J. 2012, 443, 851-856. [CrossRef]

71. E Cansizoglu, A.; Lee, B.J.; Zhang, Z.C.; A Fontoura, B.M.; Chook, Y.M. Structure-based design of a pathway-specific nuclear import inhibitor. Nat. Struct. Mol. Biol. 2007, 14, 452-454. [CrossRef]

72. Izaurralde, E.; Kutay, U.; von Kobbe, C.; Mattaj, I.; Görlich, D. The asymmetric distribution of the constituents of the Ran system is essential for transport into and out of the nucleus. EMBO J. 1997, 16, 6535-6547. [CrossRef] [PubMed]

73. Haruki, H.; Nishikawa, J.; Laemmli, U.K. The Anchor-Away Technique: Rapid, Conditional Establishment of Yeast Mutant Phenotypes. Mol. Cell 2008, 31, 925-932. [CrossRef] [PubMed]

74. Cardarelli, F.; Bizzarri, R.; Serresi, M.; Albertazzi, L.; Beltram, F. Probing Nuclear Localization Signal-Importin $\alpha$ Binding Equilibria in Living Cells. J. Biol. Chem. 2009, 284, 36638-36646. [CrossRef] [PubMed]

75. Meinema, A.C.; Poolman, B.; Veenhoff, L.M. Quantitative Analysis of Membrane Protein Transport Across the Nuclear Pore Complex. Traffic 2013, 14, 487-501. [CrossRef] [PubMed]

76. Adam, S.; Marr, R.S.; Gerace, L. Nuclear protein import in permeabilized mammalian cells requires soluble cytoplasmic factors. J. Cell Biol. 1990, 111, 807-816. [CrossRef]

77. Schnell, U.; Dijk, F.; Sjollema, K.A.; Giepmans, B. Immunolabeling artifacts and the need for live-cell imaging. Nat. Methods 2012, 9, 152-158. [CrossRef]

78. Lohka, M.J.; Masui, Y. Roles of cytosol and cytoplasmic particles in nuclear envelope assembly and sperm pronuclear formation in cell-free preparations from amphibian eggs. J. Cell Biol. 1984, 98, 1222-1230. [CrossRef]

79. Newmeyer, D.D.; Finlay, D.R.; Forbes, D.J. In vitro transport of a fluorescent nuclear protein and exclusion of non-nuclear proteins. J. Cell Biol. 1986, 103, 2091-2102. [CrossRef]

80. Newmeyer, D.; Lucocq, J.; Bürglin, T.; De Robertis, E. Assembly in vitro of nuclei active in nuclear protein transport: ATP is required for nucleoplasmin accumulation. EMBO J. 1986, 5, 501-510. [CrossRef]

81. Newmeyer, D.D.; Forbes, D.J. Nuclear import can be separated into distinct steps in vitro: Nuclear pore binding and translocation. Cell 1988, 52, 641-653. [CrossRef]

82. Finlay, D.R.; Newmeyer, D.D.; Price, T.M.; Forbes, D.J. Inhibition of in vitro nuclear transport by a lectin that binds to nuclear pores. J. Cell Biol. 1987, 104, 189-200. [CrossRef]

83. Cassany, A.; Gerace, L. Reconstitution of Nuclear Import in Permeabilized Cells. In The Nucleus; Springer International Publishing: Basel, Switzerland, 2008; Volume 464, pp. 181-205.

84. Timney, B.L.; Novatt, J.; Agate, D.S.; Williams, R.; Zhang, W.; Chait, B.T.; Rout, M.P. Simple kinetic relationships and nonspecific competition govern nuclear import rates in vivo. J. Cell Biol. 2006, 175, 579-593. [CrossRef]

85. Hodel, A.E.; Harreman, M.T.; Pulliam, K.F.; Harben, M.E.; Holmes, J.S.; Hodel, M.R.; Berland, K.M.; Corbett, A.H. Nuclear Localization Signal Receptor Affinity Correlates with in Vivo Localization in Saccharomyces cerevisiae. J. Biol. Chem. 2006, 281, 23545-23556. [CrossRef] [PubMed]

86. D'Angelo, M.A.; Anderson, D.J.; Richard, E.; Hetzer, M.W. Nuclear Pores Form de Novo from Both Sides of the Nuclear Envelope. Science 2006, 312, 440-443. [CrossRef]

87. Görlich, D. Isolation of a protein that is essential for the first step of nuclear protein import. Cell 1994, 79, 767-778. [CrossRef]

88. Radtke, T.; Schmalz, D.; Coutavas, E.; Soliman, T.M.; Peters, R. Kinetics of protein import into isolated Xenopus oocyte nuclei. Proc. Natl. Acad. Sci. USA 2001, 98, 2407-2412. [CrossRef]

89. Kopito, R.B.; Elbaum, M. Nucleocytoplasmic transport: A thermodynamic mechanism. HFSP J. 2009, 3, 130-141. [CrossRef]

90. Kalderon, D.; Roberts, B.L.; Richardson, W.D.; Smith, A.E. A short amino acid sequence able to specify nuclear location. Cell 1984, 39, 499-509. [CrossRef] 
91. Lee, D.C.Y.; Aitchison, J.D. Kap104p-mediated Nuclear Import. J. Biol. Chem. 1999, 274, 29031-29037. [CrossRef]

92. Kobayashi, J.; Matsuura, Y. Structural Basis for Cell-Cycle-Dependent Nuclear Import Mediated by the Karyopherin Kap121p. J. Mol. Biol. 2013, 425, 1852-1868. [CrossRef]

93. Mackmull, M.; Klaus, B.; Heinze, I.; Chokkalingam, M.; Beyer, A.; Russell, R.B.; Ori, A.; Beck, M. Landscape of nuclear transport receptor cargo specificity. Mol. Syst. Biol. 2017, 13, 962. [CrossRef]

94. Yang, W.; Musser, S.M. Nuclear import time and transport efficiency depend on importin $\beta$ concentration. J. Cell Biol. 2006, 174, 951-961. [CrossRef]

95. Kim, S.; Elbaum, M. A Simple Kinetic Model with Explicit Predictions for Nuclear Transport. Biophys. J. 2013, 105, 565-569. [CrossRef]

96. Ribbeck, K.; Görlich, D. Kinetic analysis of translocation through nuclear pore complexes. EMBO J. 2001, 20, 1320-1330. [CrossRef]

97. Miyamoto, Y.; Saiwaki, T.; Yamashita, J.; Yasuda, Y.; Kotera, I.; Shibata, S.; Shigeta, M.; Hiraoka, Y.; Haraguchi, T.; Yoneda, Y. Cellular stresses induce the nuclear accumulation of importin $\alpha$ and cause a conventional nuclear import block. J. Cell Biol. 2004, 165, 617-623. [CrossRef] [PubMed]

98. Kodiha, M.; Bański, P.; Ho-Wo-Cheong, D.; Stochaj, U. Dissection of the molecular mechanisms that control the nuclear accumulation of transport factors importin- $\alpha$ and CAS in stressed cells. Cell. Mol. Life Sci. 2008, 65, 1756-1767. [CrossRef] [PubMed]

99. Fujimura, K.; Suzuki, T.; Yasuda, Y.; Murata, M.; Katahira, J.; Yoneda, Y. Identification of importin $\alpha 1$ as a novel constituent of RNA stress granules. Biochim. Biophys. Acta (BBA) Bioenerg. 2010, 1803, 865-871. [CrossRef]

100. Makkerh, J.P.; Dingwall, C.; Laskey, R.A. Comparative mutagenesis of nuclear localization signals reveals the importance of neutral and acidic amino acids. Curr. Biol. 1996, 6, 1025-1027. [CrossRef]

101. Dang, C.V.; Lee, W.M. Identification of the human c-myc protein nuclear translocation signal. Mol. Cell. Biol. 1988, 8, 4048-4054 [CrossRef] [PubMed]

102. Robbins, J.; Dilwortht, S.M.; Laskey, R.A.; Dingwall, C. Two interdependent basic domains in nucleoplasmin nuclear targeting sequence: Identification of a class of bipartite nuclear targeting sequence. Cell 1991, 64, 615-623. [CrossRef]

103. Lee, B.J.; Cansizoglu, A.E.; Süel, K.E.; Louis, T.H.; Zhang, Z.; Chook, Y.M. Rules for Nuclear Localization Sequence Recognition by Karyopherin $\beta 2$. Cell 2006, 126, 543-558. [CrossRef] [PubMed]

104. Gal, J.; Zhang, J.; Kwinter, D.M.; Zhai, J.; Jia, H.; Jia, J.; Zhu, H. Nuclear localization sequence of FUS and induction of stress granules by ALS mutants. Neurobiol. Aging 2011, 32, 2323.e27-2323.e40. [CrossRef] [PubMed]

105. Fischer, U.; Huber, J.; Boelens, W.C.; Mattaj, I.; Lührmann, R. The HIV-1 Rev Activation Domain is a nuclear export signal that accesses an export pathway used by specific cellular RNAs. Cell 1995, 82, 475-483. [CrossRef]

106. Wen, W.; Meinkotht, J.L.; Tsien, R.Y.; Taylor, S.S. Identification of a signal for rapid export of proteins from the nucleus. Cell 1995, 82, 463-473. [CrossRef]

107. Dormann, D.; Rodde, R.; Edbauer, D.; Bentmann, E.; Fischer, I.; Hruscha, A.; Than, M.E.; Mackenzie, I.R.; Capell, A.; Schmid, B.; et al. ALS-associated fused in sarcoma (FUS) mutations disrupt Transportin-mediated nuclear import. EMBO J. 2010, 29, 2841-2857. [CrossRef]

108. Rebane, A.; Aab, A.; Steitz, J.A. Transportins 1 and 2 are redundant nuclear import factors for hnRNP A1 and HuR. RNA 2004, 10, 590-599. [CrossRef]

109. Sekimoto, T.; Imamoto, N.; Nakajima, K.; Hirano, T.; Yoneda, Y. Extracellular signal-dependent nuclear import of Stat1 is mediated by nuclear pore-targeting complex formation with NPI-1, but not Rch1. EMBO J. 1997, 16, 7067-7077. [CrossRef]

110. Miyamoto, Y.; Imamoto, N.; Sekimoto, T.; Tachibana, T.; Seki, T.; Tada, S.; Enomoto, T.; Yoneda, Y. Differential Modes of Nuclear Localization Signal (NLS) Recognition by Three Distinct Classes of NLS Receptors. J. Biol. Chem. 1997, 272, 26375-26381. [CrossRef]

111. Rout, M.; Blobel, G.; Aitchison, J.D. A Distinct Nuclear Import Pathway Used by Ribosomal Proteins. Cell 1997, 89, 715-725. [CrossRef]

112. Sydorskyy, Y.; Dilworth, D.J.; Yi, E.C.; Goodlett, D.R.; Wozniak, R.W.; Aitchison, J.D. Intersection of the Kap123p-Mediated Nuclear Import and Ribosome Export Pathways. Mol. Cell. Biol. 2003, 23, 2042-2054. [CrossRef]

113. Truant, R.; Kang, Y.; Cullen, B.R. The Human Tap Nuclear RNA Export Factor Contains a Novel Transportin-dependent Nuclear Localization Signal That Lacks Nuclear Export Signal Function. J. Biol. Chem. 1999, 274, 32167-32171. [CrossRef]

114. Guttinger, S.; Muhlhausser, P.; Koller-Eichhorn, R.; Brennecke, J.; Kutay, U. From The Cover: Transportin2 functions as importin and mediates nuclear import of HuR. Proc. Natl. Acad. Sci. USA 2004, 101, 2918-2923. [CrossRef] [PubMed]

115. Imasaki, T.; Shimizu, T.; Hashimoto, H.; Hidaka, Y.; Kose, S.; Imamoto, N.; Yamada, M.; Sato, M. Structural Basis for Substrate Recognition and Dissociation by Human Transportin 1. Mol. Cell 2007, 28, 57-67. [CrossRef]

116. Zhang, Z.C.; Satterly, N.; Fontoura, B.M.A.; Chook, Y.M. Evolutionary development of redundant nuclear localization signals in the mRNA export factor NXF1. Mol. Biol. Cell 2011, 22, 4657-4668. [CrossRef]

117. Kimura, M.; Kose, S.; Okumura, N.; Imai, K.; Furuta, M.; Sakiyama, N.; Tomii, K.; Horton, P.; Takao, T.; Imamoto, N. Identification of Cargo Proteins Specific for the Nucleocytoplasmic Transport Carrier Transportin by Combination of an in Vitro Transport System and Stable Isotope Labeling by Amino Acids in Cell Culture (SILAC)-based Quantitative Proteomics. Mol. Cell. Proteom. 2013, 12, 145-157. [CrossRef] [PubMed] 
118. Moore, J.D.; Yang, J.; Truant, R.; Kornbluth, S. Nuclear Import of Cdk/Cyclin Complexes: Identification of Distinct Mechanisms for Import of Cdk2/Cyclin E and Cdc2/Cyclin B1. J. Cell Biol. 1999, 144, 213-224. [CrossRef]

119. Yang, J.; Bardes, E.S.; Moore, J.D.; Brennan, J.; Powers, M.A.; Kornbluth, S. Control of Cyclin B1 localization through regulated binding of the nuclear export factor CRM1. Genes Dev. 1998, 12, 2131-2143. [CrossRef]

120. Truant, R.; Cullen, B.R. The Arginine-Rich Domains Present in Human Immunodeficiency Virus Type 1 Tat and Rev Function as Direct Importin $\beta$-Dependent Nuclear Localization Signals. Mol. Cell. Biol. 1999, 19, 1210-1217. [CrossRef] [PubMed]

121. Ho, J.H.-N.; Kallstrom, G.; Johnson, A.W. Nmd3p Is a Crm1p-Dependent Adapter Protein for Nuclear Export of the Large Ribosomal Subunit. J. Cell Biol. 2000, 151, 1057-1066. [CrossRef]

122. Gadal, O.; Strauß, D.; Kessl, J.; Trumpower, B.; Tollervey, D.; Hurt, E. Nuclear Export of 60S Ribosomal Subunits Depends on Xpo1p and Requires a Nuclear Export Sequence-Containing Factor, Nmd3p, That Associates with the Large Subunit Protein Rpl10p. Mol. Cell. Biol. 2001, 21, 3405-3415. [CrossRef]

123. Xiao, C.-Y.; Jans, P.; Jans, D.A. Negative charge at the protein kinase CK2 site enhances recognition of the SV40 large T-antigen NLS by importin: Effect of conformation. FEBS Lett. 1998, 440, 297-301. [CrossRef]

124. Hu, W.; Jans, D.A. Efficiency of Importin $\alpha / \beta$-Mediated Nuclear Localization Sequence Recognition and Nuclear Import. J. Biol. Chem. 1999, 274, 15820-15827. [CrossRef]

125. Engelsma, D.; Bernad, R.; Calafat, J.; Fornerod, M. Supraphysiological nuclear export signals bind CRM1 independently of RanGTP and arrest at Nup358. EMBO J. 2004, 23, 3643-3652. [CrossRef]

126. Feldherr, C.; Akin, D. Stimulation of nuclear import by simian virus 40-transformed cell extracts is dependent on protein kinase activity. Mol. Cell. Biol. 1995, 15, 7043-7049. [CrossRef] [PubMed]

127. Kehlenbach, R.; Gerace, L. Phosphorylation of the Nuclear Transport Machinery Down-regulates Nuclear Protein Import in Vitro. J. Biol. Chem. 2000, 275, 17848-17856. [CrossRef] [PubMed]

128. Hübner, S.; Xiao, C.-Y.; Jans, D.A. The Protein Kinase CK2 Site (Ser111/112) Enhances Recognition of the Simian Virus 40 Large T-antigen Nuclear Localization Sequence by Importin. J. Biol. Chem. 1997, 272, 17191-17195. [CrossRef]

129. Nardozzi, J.D.; Lott, K.; Cingolani, G. Phosphorylation meets nuclear import: A review. Cell Commun. Signal. 2010, 8, 1-17. [CrossRef]

130. A Jans, D. The regulation of protein transport to the nucleus by phosphorylation. Biochem. J. 1995, 311, 705-716. [CrossRef] [PubMed]

131. Poon, I.; Jans, D. Regulation of Nuclear Transport: Central Role in Development and Transformation? Traffic 2005, 6, 173-186. [CrossRef]

132. And, D.A.J.; Hubner, S. Regulation of Protein Transport to the Nucleus: Central Role of Phosphorylation. Physiol. Rev. 1996, 76, 651-685.

133. Smith, W.A.; Schurter, B.T.; Wong-Staal, F.; David, M. Arginine Methylation of RNA Helicase A Determines Its Subcellular Localization. J. Biol. Chem. 2004, 279, 22795-22798. [CrossRef]

134. Dormann, D.; Madl, T.; Valori, C.F.; Bentmann, E.; Tahirovic, S.; Abou-Ajram, C.; Kremmer, E.; Ansorge, O.; A Mackenzie, I.R.; Neumann, M.C.; et al. Arginine methylation next to the PY-NLS modulates Transportin binding and nuclear import of FUS. EMBO J. 2012, 31, 4258-4275. [CrossRef]

135. Lohrum, M.A.E.; Woods, D.B.; Ludwig, R.L.; Bálint, E.; Vousden, K.H. C-Terminal Ubiquitination of p53 Contributes to Nuclear Export. Mol. Cell. Biol. 2001, 21, 8521-8532. [CrossRef]

136. Plafker, S.M.; Plafker, K.S.; Weissman, A.M.; Macara, I.G. Ubiquitin charging of human class III ubiquitin-conjugating enzymes triggers their nuclear import. J. Cell Biol. 2004, 167, 649-659. [CrossRef]

137. Trotman, L.C.; Wang, X.; Alimonti, A.; Chen, Z.; Teruya-Feldstein, J.; Yang, H.; Pavletich, N.P.; Carver, B.S.; Cordon-Cardo, C.; Erdjument-Bromage, H.; et al. Ubiquitination Regulates PTEN Nuclear Import and Tumor Suppression. Cell 2007, 128, 141-156. [CrossRef] [PubMed]

138. Madison, D.L.; Yaciuk, P.; Kwok, R.P.S.; Lundblad, J.R. Acetylation of the Adenovirus-transforming Protein E1A Determines Nuclear Localization by Disrupting Association with Importin- $\alpha$. J. Biol. Chem. 2002, 277, 38755-38763. [CrossRef] [PubMed]

139. Santiago, A.; Li, D.; Zhao, L.Y.; Godsey, A.; Liao, D. p53 SUMOylation promotes its nuclear export by facilitating its release from the nuclear export receptor CRM1. Mol. Biol. Cell 2013, 24, 2739-2752. [CrossRef]

140. Putker, M.; Madl, T.; Vos, H.R.; de Ruiter, H.; Visscher, M.; van den Berg, M.C.W.; Kaplan, M.; Korswagen, H.C.; Boelens, R.; Vermeulen, M.; et al. Redox-Dependent Control of FOXO/DAF-16 by Transportin-1. Mol. Cell 2013, 49, 730-742. [CrossRef] [PubMed]

141. Twyffels, L.; Gueydan, C.; Kruys, V. Transportin-1 and Transportin-2: Protein nuclear import and beyond. FEBS Lett. 2014, 588, 1857-1868. [CrossRef]

142. Blank, V.; Kourilsky, P.; Israël, A. Cytoplasmic retention, DNA binding and processing of the NF-kappa B p50 precursor are controlled by a small region in its C-terminus. EMBO J. 1991, 10, 4159-4167. [CrossRef] [PubMed]

143. Traenckner, E.; Wilk, S.; Baeuerle, P. A proteasome inhibitor prevents activation of NF-kappa B and stabilizes a newly phosphorylated form of I kappa B-alpha that is still bound to NF-kappa B. EMBO J. 1994, 13, 5433-5441. [CrossRef] [PubMed]

144. Craig, E.; Zhang, Z.; Davies, K.; Kalpana, G.V. A masked NES in INI1/hSNF5 mediates hCRM1-dependent nuclear export: Implications for tumorigenesis. EMBO J. 2002, 21, 31-42. [CrossRef] 
145. Zhu, J.; McKeon, F. NF-AT activation requires suppression of Crm1-dependent export by calcineurin. Nat. Cell Biol. 1999, 398, 256-260. [CrossRef]

146. Oeckinghaus, A.; Ghosh, S. The NF-KappaB Family of Transcription Factors and Its Regulation. Cold Spring Harb. Perspect. Biol. 2009, 1, a000034. [CrossRef] [PubMed]

147. Jeyasekharan, A.; Liu, Y.; Hattori, H.; Pisupati, V.; Jonsdottir, A.B.; Rajendra, E.; Lee, M.; Sundaramoorthy, E.; Schlachter, S.; Kaminski, C.; et al. A cancer-associated BRCA2 mutation reveals masked nuclear export signals controlling localization. Nat. Struct. Mol. Biol. 2013, 20, 1191-1198. [CrossRef]

148. Fineberg, K.; Fineberg, T.; Graessmann, A.; Luedtke, N.W.; Tor, Y.; Lixin, R.; Jans, D.A.; Loyter, A. Inhibition of Nuclear Import Mediated by the Rev-Arginine Rich Motif by RNA Moleculest. Biochemistry 2003, 42, 2625-2633. [CrossRef]

149. Stommel, J.M.; Marchenko, N.D.; Jimenez, G.S.; Moll, U.M.; Hope, T.J.; Wahl, G.M. A leucine-rich nuclear export signal in the p53 tetramerization domain: Regulation of subcellular localization and p53 activity by NES masking. EMBO J. 1999, 18, 1660-1672. [CrossRef]

150. Kuge, S.; Arita, M.; Murayama, A.; Maeta, K.; Izawa, S.; Inoue, Y.; Nomoto, A. Regulation of the Yeast Yap1p Nuclear Export Signal Is Mediated by Redox Signal-Induced Reversible Disulfide Bond Formation. Mol. Cell. Biol. 2001, 21, 6139-6150. [CrossRef]

151. Nadler, S.G.; Tritschler, D.; Haffar, O.K.; Blake, J.; Bruce, A.G.; Cleaveland, J.S. Differential Expression and Sequence-specific Interaction of Karyopherin $\alpha$ with Nuclear Localization Sequences. J. Biol. Chem. 1997, 272, 4310-4315. [CrossRef] [PubMed]

152. Köhler, M.; Speck, C.; Christiansen, M.; Bischoff, F.R.; Prehn, S.; Haller, H.; Görlich, D.; Hartmann, E. Evidence for Distinct Substrate Specificities of Importin $\alpha$ Family Members in Nuclear Protein Import. Mol. Cell. Biol. 1999, 19, 7782-7791. [CrossRef]

153. Coyne, A.N.; Baskerville, V.; Zaepfel, B.L.; Dickson, D.W.; Rigo, F.; Bennett, F.; Lusk, C.P.; Rothstein, J.D. Nuclear accumulation of CHMP7 initiates nuclear pore complex injury and subsequent TDP-43 dysfunction in sporadic and familial ALS. Sci. Transl. Med. 2021, 13, eabe1923. [CrossRef]

154. Rempel, I.L.; Crane, M.M.; Thaller, D.J.; Mishra, A.; Jansen, D.P.; Janssens, G.; Popken, P.; Akşit, A.; Kaeberlein, M.; Van Der Giessen, E.; et al. Age-dependent deterioration of nuclear pore assembly in mitotic cells decreases transport dynamics. eLife 2019, 8, e48186. [CrossRef] [PubMed]

155. Bernad, R.; van der Velde, H.; Fornerod, M.; Pickersgill, H. Nup358/RanBP2 Attaches to the Nuclear Pore Complex via Association with Nup88 and Nup214/CAN and Plays a Supporting Role in CRM1-Mediated Nuclear Protein Export. Mol. Cell. Biol. 2004, 24, 2373-2384. [CrossRef]

156. Bernad, R.; Engelsma, D.; Sanderson, H.; Pickersgill, H.; Fornerod, M. Nup214-Nup88 Nucleoporin Subcomplex Is Required for CRM1-mediated 60 S Preribosomal Nuclear Export. J. Biol. Chem. 2006, 281, 19378-19386. [CrossRef] [PubMed]

157. Hutten, S.; Kehlenbach, R. Nup214 Is Required for CRM1-Dependent Nuclear Protein Export In Vivo. Mol. Cell. Biol. 2006, 26, 6772-6785. [CrossRef] [PubMed]

158. Roloff, S.; Spillner, C.; Kehlenbach, R.H. Several Phenylalanine-Glycine Motives in the Nucleoporin Nup214 Are Essential for Binding of the Nuclear Export Receptor CRM1. J. Biol. Chem. 2013, 288, 3952-3963. [CrossRef]

159. Waldmann, I.; Spillner, C.; Kehlenbach, R.H. The nucleoporin-like protein NLP1 (hCG1) promotes CRM1-dependent nuclear protein export. J. Cell Sci. 2012, 125, 144-154. [CrossRef]

160. Takeda, A.; Sarma, N.J.; Abdul-Nabi, A.M.; Yaseen, N.R. Inhibition of CRM1-mediated Nuclear Export of Transcription Factors by Leukemogenic NUP98 Fusion Proteins. J. Biol. Chem. 2010, 285, 16248-16257. [CrossRef]

161. Oka, M.; Asally, M.; Yasuda, Y.; Ogawa, Y.; Tachibana, T.; Yoneda, Y. The Mobile FG Nucleoporin Nup98 Is a Cofactor for Crm1-dependent Protein Export. Mol. Biol. Cell 2010, 21, 1885-1896. [CrossRef]

162. Kim, S.; Elbaum, M. Enzymatically Driven Transport: A Kinetic Theory for Nuclear Export. Biophys. J. 2013, 105, 1997-2005. [CrossRef]

163. Zeitler, B.; Weis, K. The FG-repeat asymmetry of the nuclear pore complex is dispensable for bulk nucleocytoplasmic transport in vivo. J. Cell Biol. 2004, 167, 583-590. [CrossRef]

164. Pyhtila, B.; Rexach, M. A Gradient of Affinity for the Karyopherin Kap95p along the Yeast Nuclear Pore Complex. J. Biol. Chem. 2003, 278, 42699-42709. [CrossRef] [PubMed]

165. Shulga, N.; Mosammaparast, N.; Wozniak, R.; Goldfarb, D.S. Yeast Nucleoporins Involved in Passive Nuclear Envelope Permeability. J. Cell Biol. 2000, 149, 1027-1038. [CrossRef] [PubMed]

166. Makhnevych, T.; Lusk, C.P.; Anderson, A.M.; Aitchison, J.D.; Wozniak, R.W. Cell Cycle Regulated Transport Controlled by Alterations in the Nuclear Pore Complex. Cell 2003, 115, 813-823. [CrossRef]

167. Fan, F.; Liu, C.-P.; Korobova, O.; Heyting, C.; Offenberg, H.H.; Trump, G.; Arnheim, N. cDNA Cloning and Characterization ofNpap60:A Novel Rat Nuclear Pore-Associated Protein with an Unusual Subcellular Localization during Male Germ Cell Differentiation. Genomics 1997, 40, 444-453. [CrossRef]

168. Olsson, M.; Schéele, S.; Ekblom, P. Limited expression of nuclear pore membrane glycoprotein 210 in cell lines and tissues suggests cell-type specific nuclear pores in metazoans. Exp. Cell Res. 2004, 292, 359-370. [CrossRef]

169. Ori, A.; Banterle, N.; Iskar, M.; Andres-Pons, A.; Escher, C.; Bui, H.K.; Sparks, L.; Solis-Mezarino, V.; Rinner, O.; Bork, P.; et al. Cell type-specific nuclear pores: A case in point for context-dependent stoichiometry of molecular machines. Mol. Syst. Biol. 2013, 9 , 648. [CrossRef]

170. Gomez-Cavazos, J.S.; Hetzer, M.W. The nucleoporin gp210/Nup210 controls muscle differentiation by regulating nuclear envelope/ER homeostasis. J. Cell Biol. 2015, 208, 671-681. [CrossRef] 
171. Kane, M.; Rebensburg, S.V.; A Takata, M.; Zang, T.M.; Yamashita, M.; Kvaratskhelia, M.; Bieniasz, P.D. Nuclear pore heterogeneity influences HIV-1 infection and the antiviral activity of MX2. eLife 2018, 7, e35738. [CrossRef]

172. Lupu, F.; Alves, A.; Anderson, K.; Doye, V.; Lacy, E. Nuclear Pore Composition Regulates Neural Stem/Progenitor Cell Differentiation in the Mouse Embryo. Dev. Cell 2008, 14, 831-842. [CrossRef]

173. D'Angelo, M.; Raices, M.; Panowski, S.H.; Hetzer, M.W. Age-Dependent Deterioration of Nuclear Pore Complexes Causes a Loss of Nuclear Integrity in Postmitotic Cells. Cell 2009, 136, 284-295. [CrossRef]

174. Prieve, M.G.; Guttridge, K.L.; Munguia, J.E.; Waterman, M.L. The Nuclear Localization Signal of Lymphoid Enhancer Factor-1 Is Recognized by Two Differentially Expressed Srp1-Nuclear Localization Sequence Receptor Proteins. J. Biol. Chem. 1996, 271, 7654-7658. [CrossRef]

175. Tsuji, L.; Takumi, T.; Imamoto, N.; Yoneda, Y. Identification of novel homologues of mouse importin $\alpha$, the $\alpha$ subunit of the nuclear pore-targeting complex, and their tissue-specific expression. FEBS Lett. 1997, 416, 30-34. [CrossRef]

176. Köhler, M.; Ansieau, S.; Prehn, S.; Leutz, A.; Haller, H.; Hartmann, E. Cloning of two novel human importin- $\alpha$ subunits and analysis of the expression pattern of the importin- $\alpha$ protein family. FEBS Lett. 1997, 417, 104-108. [CrossRef]

177. Nachury, M.; Ryder, U.W.; Lamond, A.; Weis, K. Cloning and characterization of hSRP1, a tissue-specific nuclear transport factor. Proc. Natl. Acad. Sci. USA 1998, 95, 582-587. [CrossRef] [PubMed]

178. Dahl, E.; Kristiansen, G.; Gottlob, K.; Klaman, I.; Ebner, E.; Hinzmann, B.; Hermann, K.; Pilarsky, C.; Dürst, M.; KlinkhammerSchalke, M.; et al. Molecular Profiling of Laser-Microdissected Matched Tumor and Normal Breast Tissue Identifies Karyopherin $\alpha 2$ as a Potential Novel Prognostic Marker in Breast Cancer. Clin. Cancer Res. 2006, 12, 3950-3960. [CrossRef] [PubMed]

179. Brinkmann, U.; Gallo, M.; Polymeropoulos, M.H.; Pastan, I. The human CAS (cellular apoptosis susceptibility) gene mapping on chromosome 20q13 is amplified in BT474 breast cancer cells and part of aberrant chromosomes in breast and colon cancer cell lines. Genome Res. 1996, 6, 187-194. [CrossRef] [PubMed]

180. Behrens, P.; Brinkmann, U.; Fogt, F.; Wernert, N.; Wellmann, A. Implication of the Proliferation and Apoptosis Associated CSE1L/CAS Gene for Breast Cancer Development. Anticancer. Res. 2001, 21, 2413-2417.

181. Wellmann, A.; Flemming, P.; Behrens, P.; Wuppermann, K.; Lang, H.; Oldhafer, K.; Pastan, I.; Brinkmann, U. High expression of the proliferation and apoptosis associated CSE1L/CAS gene in hepatitis and liver neoplasms: Correlation with tumor progression. Int. J. Mol. Med. 2001, 7, 489-494. [CrossRef]

182. Van der Watt, P.J.; Maske, C.P.; Hendricks, D.T.; Parker, M.I.; Denny, L.; Govender, D.; Birrer, M.J.; Leaner, V.D. The Karyopherin proteins, Crm1 and Karyopherin $\beta 1$, are overexpressed in cervical cancer and are critical for cancer cell survival and proliferation. Int. J. Cancer 2009, 124, 1829-1840. [CrossRef] [PubMed]

183. Ishizawa, J.; Kojima, K.; Hail, N.; Tabe, Y.; Andreeff, M. Expression, function, and targeting of the nuclear exporter chromosome region maintenance 1 (CRM1) protein. Pharmacol. Ther. 2015, 153, 25-35. [CrossRef] [PubMed]

184. Saulino, D.M.; Younes, P.S.; Bailey, J.M.; Younes, M. CRM1/XPO1 expression in pancreatic adenocarcinoma correlates with survivin expression and the proliferative activity. Oncotarget 2018, 9, 21289-21295. [CrossRef] [PubMed]

185. Gao, W.; Lu, C.; Chen, L.; Keohavong, P. Overexpression of CRM1: A Characteristic Feature in a Transformed Phenotype of Lung Carcinogenesis and a Molecular Target for Lung Cancer Adjuvant Therapy. J. Thorac. Oncol. 2015, 10, 815-825. [CrossRef]

186. Noske, A.; Weichert, W.; Niesporek, S.; Röske, A.; Buckendahl, A.-C.; Koch, I.; Sehouli, J.; Dietel, M.; Denkert, C. Expression of the nuclear export protein chromosomal region maintenance/exportin 1/Xpo1 is a prognostic factor in human ovarian cancer. Cancer 2008, 112, 1733-1743. [CrossRef]

187. Huang, W.-Y.; Yue, L.; Qiu, W.-S.; Wang, L.-W.; Zhou, X.-H.; Sun, Y.-J. Prognostic value of CRM1in pancreas cancer. Clin. Investig. Med. 2009, 32, E315-E321. [CrossRef]

188. Shen, P.A.; Wang, M.Y.; Zhao, M.Y.; Zou, M.L.; Sun, M.L.; Cheng, M.C. Expression of crm1 in human gliomas and its significance in p27 expression and clinical prognosis. Neurosurgery 2009, 65, 153-160. [CrossRef]

189. Ho, Y.; Yao, Y.; Dong, Y.; Lin, F.; Zhao, H.; Shen, Z.; Chen, P.; Sun, Y.-J.; Tang, L.-N.; Zheng, S.-E. The expression of CRM1 is associated with prognosis in human osteosarcoma. Oncol. Rep. 1994, 21, 229-235. [CrossRef]

190. Fang, X.-D.; Chen, T.; Tran, K.; Parker, C.S. Developmental regulation of the heat shock response by nuclear transport factor karyopherin- $\alpha 3$. Development 2001, 128, 3349-3358. [CrossRef] [PubMed]

191. Giarrè, M.; Török, I.; Schmitt, R.; Gorjánácz, M.; Kiss, I.; Mechler, B.M. Patterns of Importin- $\alpha$ Expression during Drosophila Spermatogenesis. J. Struct. Biol. 2002, 140, 279-290. [CrossRef]

192. Koehler, M.; Fiebeler, A.; Hartwig, M.; Thiel, S.; Prehn, S.; Kettritz, R.; Luft, F.; Hartmann, E. Differential Expression of Classical Nuclear Transport Factors During Cellular Proliferation and Differentiation. Cell. Physiol. Biochem. 2002, 12, 335-344. [CrossRef]

193. Yasuhara, N.; Shibazaki, N.; Tanaka, S.; Nagai, M.; Kamikawa, Y.; Oe, S.; Asally, M.; Kamachi, Y.; Kondoh, H.; Yoneda, Y. Triggering neural differentiation of ES cells by subtype switching of importin- $\alpha$. Nat. Cell Biol. 2006, 9, 72-79. [CrossRef]

194. Wen, X.; Tan, W.; Westergard, T.; Krishnamurthy, K.; Markandaiah, S.S.; Shi, Y.; Lin, S.; Shneider, N.; Monaghan, J.; Pandey, U.B.; et al. Antisense Proline-Arginine RAN Dipeptides Linked to C9ORF72-ALS/FTD Form Toxic Nuclear Aggregates that Initiate In Vitro and In Vivo Neuronal Death. Neuron 2014, 84, 1213-1225. [CrossRef]

195. Tao, Z.; Wang, H.; Xia, Q.; Li, K.; Li, K.; Jiang, X.; Xu, G.; Wang, G.; Ying, Z. Nucleolar stress and impaired stress granule formation contribute to C9orf72 RAN translation-induced cytotoxicity. Hum. Mol. Genet. 2015, 24, 2426-2441. [CrossRef]

196. Swaminathan, A.; Bouffard, M.; Liao, M.; Ryan, S.; Callister, J.B.; Pickering-Brown, S.; Armstrong, G.; Drapeau, P. Expression of C9orf72-related dipeptides impairs motor function in a vertebrate model. Hum. Mol. Genet. 2018, 27, 1754-1762. [CrossRef] 
197. Schludi, M.H.; German Consortium for Frontotemporal Lobar Degeneration; May, S.; Grässer, F.A.; Rentzsch, K.; Kremmer, E.; Küpper, C.; Klopstock, T.; Arzberger, T.; Edbauer, D.; et al. Distribution of dipeptide repeat proteins in cellular models and C9orf72 mutation cases suggests link to transcriptional silencing. Acta Neuropathol. 2015, 130, 537-555. [CrossRef]

198. Zu, T.; Liu, Y.; Bañez-Coronel, M.; Reid, T.; Pletnikova, O.; Lewis, J.; Miller, T.M.; Harms, M.B.; Falchook, A.E.; Subramony, S.H.; et al. RAN proteins and RNA foci from antisense transcripts in C9ORF72 ALS and frontotemporal dementia. Proc. Natl. Acad. Sci. USA 2013, 110, E4968-E4977. [CrossRef] [PubMed]

199. Rudich, P.; Snoznik, C.; Watkins, S.; Monaghan, J.; Pandey, U.B.; Lamitina, S.T. Nuclear localized C9orf72-associated argininecontaining dipeptides exhibit age-dependent toxicity in C. elegans. Hum. Mol. Genet. 2017, 26, 4916-4928. [CrossRef]

200. Lee, K.-H.; Zhang, P.; Kim, H.J.; Mitrea, D.M.; Sarkar, M.; Freibaum, B.D.; Cika, J.; Coughlin, M.; Messing, J.; Molliex, A.; et al. C9orf72 Dipeptide Repeats Impair the Assembly, Dynamics, and Function of Membrane-Less Organelles. Cell 2016, 167, 774-788e17. [CrossRef] [PubMed]

201. Kwon, I.; Xiang, S.; Kato, M.; Wu, L.; Theodoropoulos, P.; Wang, T.; Kim, J.; Yun, J.; Xie, Y.; McKnight, S.L. Poly-dipeptides encoded by the C9orf72 repeats bind nucleoli, impede RNA biogenesis, and kill cells. Science 2014, 345, 1139-1145. [CrossRef] [PubMed]

202. Callister, J.B.; Ryan, S.; Sim, J.; Rollinson, S.; Pickering-Brown, S.M. Modelling C9orf72 dipeptide repeat proteins of a physiologically relevant size. Hum. Mol. Genet. 2016, 25, 5069-5082. [CrossRef] [PubMed]

203. Yang, D.; Abdallah, A.; Li, Z.; Lu, Y.; Almeida, S.; Gao, F.-B. FTD/ALS-associated poly(GR) protein impairs the Notch pathway and is recruited by poly(GA) into cytoplasmic inclusions. Acta Neuropathol. 2015, 130, 525-535. [CrossRef] [PubMed]

204. Kanekura, K.; Yagi, T.; Cammack, A.J.; Mahadevan, J.; Kuroda, M.; Harms, M.B.; Miller, T.M.; Urano, F. Poly-dipeptides encoded by the C9ORF72 repeats block global protein translation. Hum. Mol. Genet. 2016, 25, 1803-1813. [CrossRef] [PubMed]

205. Zhang, Y.-J.; Jansen-West, K.; Xu, Y.-F.; Gendron, T.F.; Bieniek, K.; Lin, W.-L.; Sasaguri, H.; Caulfield, T.; Hubbard, J.; Daughrity, L.; et al. Aggregation-prone c9FTD/ALS poly(GA) RAN-translated proteins cause neurotoxicity by inducing ER stress. Acta Neuropathol. 2014, 128, 505-524. [CrossRef] [PubMed]

206. May, S.; Hornburg, D.; Schludi, M.H.; Arzberger, T.; Rentzsch, K.; Schwenk, B.M.; Grässer, F.A.; Mori, K.; Kremmer, E.; BanzhafStrathmann, J.; et al. C9orf72 FTLD/ALS-associated Gly-Ala dipeptide repeat proteins cause neuronal toxicity and Unc119 sequestration. Acta Neuropathol. 2014, 128, 485-503. [CrossRef]

207. Gill, A.L.; Wang, M.Z.; Levine, B.; Premasiri, A.; Vieira, F.G. Primary Neurons and Differentiated NSC-34 Cells Are More Susceptible to Arginine-Rich ALS Dipeptide Repeat Protein-Associated Toxicity than Non-Differentiated NSC-34 and CHO Cells. Int. J. Mol. Sci. 2019, 20, 6238. [CrossRef]

208. Boeynaems, S.; Bogaert, E.; Kovacs, D.; Konijnenberg, A.; Timmerman, E.; Volkov, A.; Guharoy, M.; De Decker, M.; Jaspers, T.; Ryan, V.; et al. Phase Separation of C9orf72 Dipeptide Repeats Perturbs Stress Granule Dynamics. Mol. Cell 2017, 65, 1044-1055e5. [CrossRef]

209. Seibel, N.M.; Eljouni, J.; Nalaskowski, M.M.; Hampe, W. Nuclear localization of enhanced green fluorescent protein homomultimers. Anal. Biochem. 2007, 368, 95-99. [CrossRef]

210. Zhang, Y.-J.; Gendron, T.F.; Ebbert, M.T.W.; O’Raw, A.; Yue, M.; Jansen-West, K.; Zhang, X.; Prudencio, M.; Chew, J.; Cook, C.N.; et al. Poly(GR) impairs protein translation and stress granule dynamics in C9orf72-associated frontotemporal dementia and amyotrophic lateral sclerosis. Nat. Med. 2018, 24, 1136-1142. [CrossRef]

211. MacKenzie, I.R.A.; Frick, P.; Grässer, F.A.; Gendron, T.F.; Petrucelli, L.; Cashman, N.R.; Edbauer, D.; Kremmer, E.; Prudlo, J.; Troost, D.; et al. Quantitative analysis and clinico-pathological correlations of different dipeptide repeat protein pathologies in C9ORF72 mutation carriers. Acta Neuropathol. 2015, 130, 845-861. [CrossRef]

212. Lopez-Gonzalez, R.; Lu, Y.; Gendron, T.F.; Karydas, A.; Tran, H.; Yang, D.; Petrucelli, L.; Miller, B.L.; Almeida, S.; Gao, F.-B Poly(GR) in C9ORF72 -Related ALS/FTD Compromises Mitochondrial Function and Increases Oxidative Stress and DNA Damage in iPSC-Derived Motor Neurons. Neuron 2016, 92, 383-391. [CrossRef]

213. Yamakawa, M.; Ito, D.; Honda, T.; Kubo, K.-I.; Noda, M.; Nakajima, K.; Suzuki, N. Characterization of the dipeptide repeat protein in the molecular pathogenesis of c9FTD/ALS. Hum. Mol. Genet. 2015, 24, 1630-1645. [CrossRef]

214. Gupta, R.; Lan, M.; Mojsilovic-Petrovic, J.; Choi, W.H.; Safren, N.; Barmada, S.; Lee, M.J.; Kalb, R. The Proline/Arginine Dipeptide from Hexanucleotide Repeat Expanded C9ORF72 Inhibits the Proteasome. Eneuro 2017, 4. [CrossRef] [PubMed]

215. Kramer, N.J.; Haney, M.S.; Morgens, D.W.; Jovičić, A.; Couthouis, J.; Li, A.; Ousey, J.; Ma, R.; Bieri, G.; Tsui, C.K.; et al. CRISPRCas9 screens in human cells and primary neurons identify modifiers of C9ORF72 dipeptide-repeat-protein toxicity. Nat. Genet. 2018, 50, 603-612. [CrossRef] [PubMed]

216. Mizielinska, S.; Grönke, S.; Niccoli, T.; Ridler, C.E.; Clayton, E.L.; Devoy, A.; Moens, T.; Norona, F.E.; Woollacott, I.O.C.; Pietrzyk, J.; et al. C9orf72 repeat expansions cause neurodegeneration in Drosophila through arginine-rich proteins. Science 2014, 345, 1192-1194. [CrossRef] [PubMed] 